\title{
Synthesis, Crystal Structure, Structure-Activity Relationships, and Antiviral Activity of a Potent SARS Coronavirus 3CL Protease Inhibitor
}

\author{
Syaulan Yang, ${ }^{\dagger}$ Shu-Jen Chen, ${ }^{\dagger}, \#$ Min-Feng Hsu, $,{ }^{\ddagger},\|\| \$,$# Jen-Dar Wu, { }^{\dagger, \#}$ Chien-Te K. Tseng, ${ }^{\perp}$ Yu-Fan Liu, ${ }^{\dagger}$ Hua-Chien Chen, \\ Chun-Wei Kuo, ${ }^{\dagger}$ Chi-Shen Wu ${ }^{\dagger}$ Li-Wen Chang, ${ }^{\dagger}$ Wen-Chang Chen,${ }^{\dagger}$ Shao-Ying Liao, ${ }^{\dagger}$ Teng-Yuan Chang, ${ }^{\dagger}$ Hsin-Hui Hung, ${ }^{\dagger}$ \\ Hui-Lin Shr ${ }^{\S, l}$ Cheng-Yuan Liu, ${ }^{\dagger}$ Yu-An Huang, ${ }^{\dagger}$ Ling-Yin Chang, ${ }^{\dagger}$ Jen-Chi Hsu, ${ }^{\dagger}$ Clarence J. Peters, ${ }^{*, \perp}$ \\ Andrew H.-J. Wang, $*, \$,, \| l$ and Ming-Chu Hsu*,† \\ TaiGen Biotechnology Co., Taipei 114, Taiwan, ROC, Institute of Biochemical Sciences, National Taiwan University, Taipei 106, Taiwan, \\ ROC, Institute of Biological Chemistry, Academia Sinica, Taipei 115, Taiwan, ROC, Core Facility for Protein X-ray Crystallography, \\ Academia Sinica, Taipei 115, Taiwan, ROC, and Department of Microbiology and Immunology, University of Texas Medical Branch, \\ Galveston, Texas 77555
}

Received April 4, 2006

A potent SARS coronavirus (CoV) 3CL protease inhibitor (TG-0205221, $K_{\mathrm{i}}=53 \mathrm{nM}$ ) has been developed. TG-0205221 showed remarkable activity against SARS CoV and human coronavirus (HCoV) 229E replications by reducing the viral titer by $4.7 \log ($ at $5 \mu \mathrm{M})$ for SARS CoV and $5.2 \log ($ at $1.25 \mu \mathrm{M})$ for HCoV 229E. The crystal structure of TG-0205221 (resolution $=1.93 \AA$ ) has revealed a unique binding mode comprising a covalent bond, hydrogen bonds, and numerous hydrophobic interactions. Structural comparisons between TG-0205221 and a natural peptide substrate were also discussed. This information may be applied toward the design of other 3CL protease inhibitors.

\section{Introduction}

The emergence of Severe Acute Respiratory Syndrome (SARS) and its causative agent, a new coronavirus (SARS CoV), ${ }^{1-5}$ in 2002 and 2003 has caused about 900 deaths among more than 8400 infected people (a fatality rate of $10-15 \%$ ) in 5 continents and 32 countries. $^{6}$ The social impact and economic loss in the affected regions, particularly in East and Southeast Asia, have been enormous. Although regional preventive measures are being implemented, vaccine and therapeutic drugs are being sought.

SARS CoV is a positive-sense, single-stranded RNA virus featuring the largest viral RNA genomes known to date. ${ }^{7-9}$ It consists of about 29700 nucleotides with its replicase gene alone encompassing more than 21000 nucleotides and encoding two overlapping polyproteins, pp1a (486 kDa) and pplab (790 $\mathrm{kDa}) .{ }^{10}$ The functional polypeptides are released from each polyprotein through extensive proteolytic processing, primarily by the $34.6 \mathrm{kDa}$ protease, which is also called the $3 \mathrm{C}$-like protease $\left(3 \mathrm{CL}^{\mathrm{pro}}\right)$. Designing small molecule inhibitors to the 3CL protease is an attractive strategy for the development of anti-SARS drugs. Such an antiviral strategy has been successfully applied to the aspartyl protease of the human immunodeficiency virus (HIV) to treat AIDS. ${ }^{11}$

Herein, we report our findings on a potent $3 \mathrm{CL}^{\text {pro }}$ inhibitor TG-0205221 $\left(K_{\mathrm{i}}=53 \mathrm{nM}\right.$, Table 1$)$ of SARS coronavirus with distinct functional groups at the $\mathrm{P} 1$ to $\mathrm{P} 4$ sites compared to those of reference compound $\mathbf{1}$, a $3 \mathrm{C}$ protease inhibitor to rhinovirus possessing low activity toward $3 \mathrm{CL}^{\text {pro }}$. The newly designed

* To whom correspondence should be addressed. Tel: +886-22790-1861 ext. 1702. Fax: +886-2-2796-3606. e-mail: mchsu@ taigenbiotech.com.tw (M.C.H.). Tel: +886-2-2788-1981. Fax: +886-22788-2043. E-mail: ahjwang@gate.sinica.edu.tw (A.H.-J.W.). Tel: +1409-772-0090. Fax: +1-409-747-0762. E-mail: cjpeters@utmb.edu (C.J.P.).

$\dagger$ TaiGen Biotechnology Co.

National Taiwan University.

$\S$ Institute of Biological Chemistry, Academia Sinica.

"Core Facility for Protein X-ray Crystallography, Academia Sinica.

$\perp$ University of Texas Medical Branch.

\# These authors contributed equally to this work. inhibitor exhibited potent activities in suppressing the replication of SARS CoV (4.7 log viral titer reduction at $5 \mu \mathrm{M}$ concentration, $\mathrm{IC}_{50}=0.6 \mu \mathrm{M}$, and cytotoxicity $\left.\mathrm{IC}_{50}>20 \mu \mathrm{M}\right)$ and human coronavirus $\mathrm{HCoV} 229 \mathrm{E}$ (5.2 log viral titer reduction at 1.25 $\mu \mathrm{M}$ concentration). The tight binding between TG-0205221 and the $3 C^{\text {pro }}$ enzyme is through a covalent bond, hydrogen bonds, and unprecedented hydrophobic interactions as evidenced by the crystal structure of the corresponding complex.

Synthesis. The preparation of $\mathbf{1 5}$ (TG-0205221) was carried out as described in Scheme 1 (the synthesis from compound 6 to 9 is similar to the ones described in ref 12): ${ }^{12}$ L-glutamic acid (5) was silylated with trimethylsilyl chloride and esterified in methanol at $0{ }^{\circ} \mathrm{C}$, followed by Boc protection to afford compound 6 in $95 \%$ yield. Sequential treatment of 6 with lithium hexamethyl disilazide in THF under $-78{ }^{\circ} \mathrm{C}$ and then with bromoacetonitrile at $-70{ }^{\circ} \mathrm{C}$ yielded alkylated product 7 in $83 \%$ yield. Compound 7 was then dissolved in acetic acid and shaken with $10 \%$ palladium on carbon under hydrogen gas in a Parr shaker at 70 psi to give crude residue $\mathbf{8}$. This residue was used without purification and treated with triethylamine in THF and then stirred overnight at $60{ }^{\circ} \mathrm{C}$ to afford cyclized product 9 in $61 \%$ overall yield. After removal of the Boc protecting group, intermediate 10 was coupled with 2-tert-butoxycarbonylamino3 - $(S)$-cyclohexyl-propionic acid in the presence of EDC, HOBt, and $\mathrm{N}$-methylmorpholine at $0-5{ }^{\circ} \mathrm{C}$ in $\mathrm{CH}_{2} \mathrm{Cl}_{2}$ to give a high yield (93\%) of compound 11. The removal of Boc from 11 was carried out by using ethereal $\mathrm{HCl}$ solution to afford intermediate 12, followed by peptide coupling of $\mathbf{1 2}$ with 2-benzyloxycarbonylamino-3-(S)-tert-butoxy-butyric acid in the presence of EDC, $\mathrm{HOBt}$, and $\mathrm{N}$-methylmorpholine at $0-5^{\circ} \mathrm{C}$ in $\mathrm{CH}_{2} \mathrm{Cl}_{2}$ to give compound $\mathbf{1 3}$ in $64 \%$ yield. Reduction of $\mathbf{1 3}$ with lithium borohydride in THF provided alcohol 14 in a 74\% yield, which was then oxidized with sulfur trioxide-pyridine complex in DMSO to afford target product 15 (TG-0205221) in 30\% yield.

\section{Results and Discussion}

Crystal Structure and Structure-Activity Relationships. The structure of SARS 3CL pro bound with TG-0205221 (resolu- 
Table 1. 3CL Protease Inhibitor on SARS Coronavirus, TG-0205221, and Reference Compound 1, Originally for 3C Protease Inhibitor on Rhinovirus

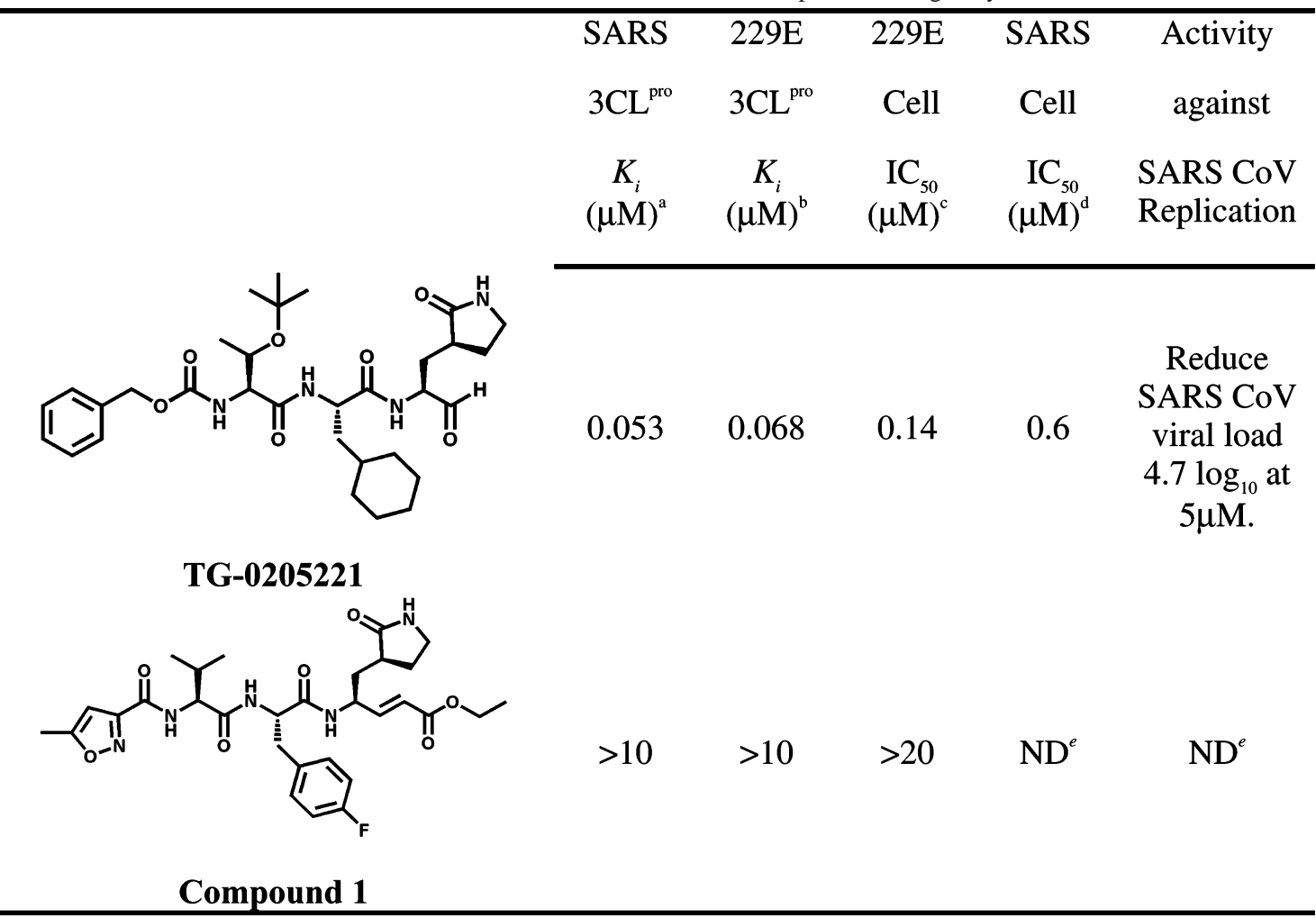

${ }^{a} K_{i}$ in $\mu \mathrm{M}$ for the in vitro inhibition of SARS coronavirus 3CL protease. ${ }^{b} K_{i}$ in $\mu \mathrm{M}$ for the in vitro inhibition of HCoV 229E $3 \mathrm{CL}$ protease. ${ }^{c}$ Drug concentration in $\mu \mathrm{M}$ showing $50 \%$ inhibition on the HCoV 229E infected in vitro in the MRC-5 cells. ${ }^{d}$ Drug concentration in $\mu \mathrm{M}$ showing $50 \%$ inhibition on the SARS coronavirus infected in vitro in the Vero-E6 cells. ${ }^{e} \mathrm{ND}=$ not determined.

Scheme $1^{a}$
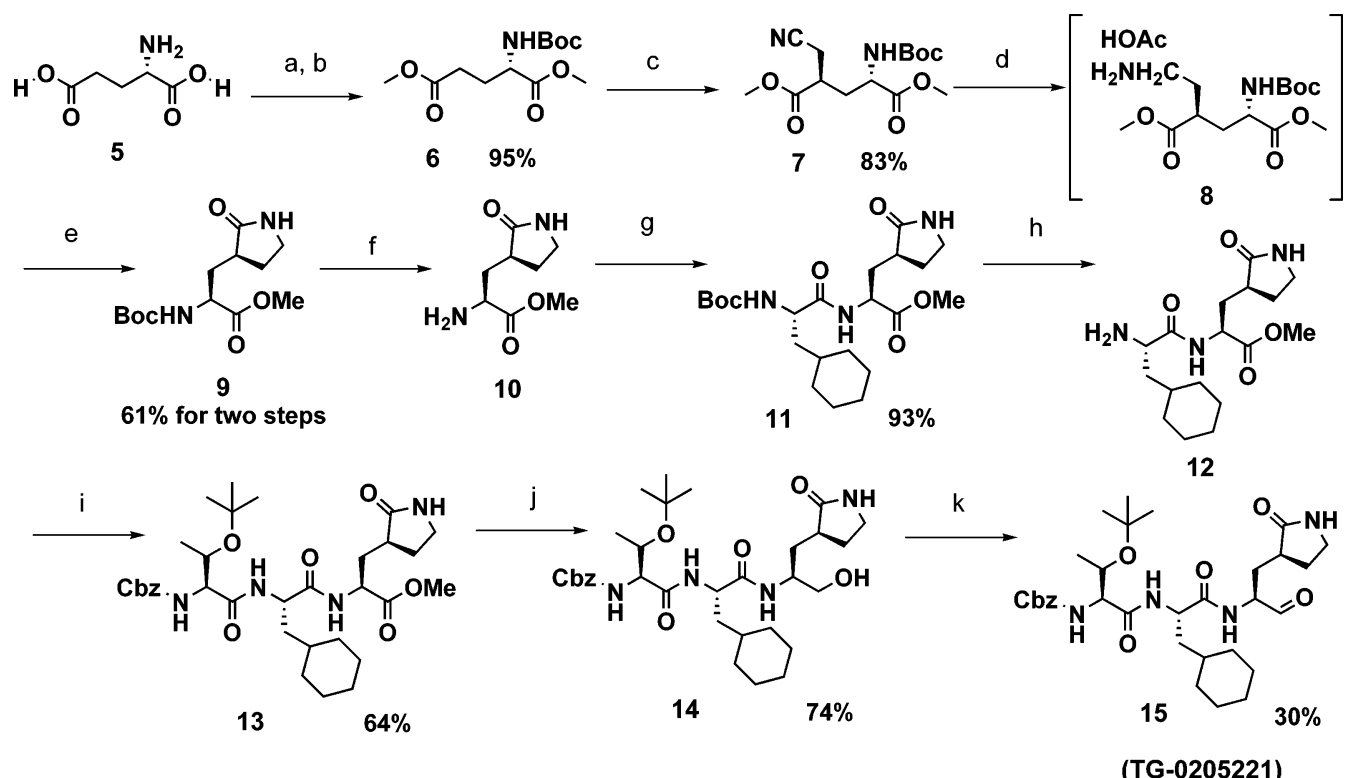

${ }^{a}$ Reagents and conditions: (a) TMSCl, $\mathrm{MeOH}, 0{ }^{\circ} \mathrm{C} \rightarrow \mathrm{rt}, 15 \mathrm{~h}$; (b) (Boc) $)_{2} \mathrm{O}, \mathrm{Et}_{3} \mathrm{~N}, \mathrm{rt}, 0.5-1 \mathrm{~h}$; (c) LiHMDS, THF, $\mathrm{N}_{2},-78{ }^{\circ} \mathrm{C}, 1.5 \mathrm{~h}$, then $\mathrm{BrCH} \mathrm{CN}$, $-78{ }^{\circ} \mathrm{C}, 3 \mathrm{~h}$; (d) $\mathrm{H}_{2}(70 \mathrm{psi}), 10 \% \mathrm{Pd} / \mathrm{C}, \mathrm{CH}_{3} \mathrm{COOH}, \mathrm{rt}, 2 \mathrm{~h}$; (e) Et $3 \mathrm{~N}$, THF, $60{ }^{\circ} \mathrm{C}$, overnight; (f) $4 \mathrm{M} \mathrm{HCl}$ in dioxane, rt, $0.5 \mathrm{~h}$; (g) Boc- $\beta$-cyclohexyl-Ala-OH, EDC, HOBt, NMM, DCM, rt, 2h; (h) $4 \mathrm{M} \mathrm{HCl}$ in dioxane, rt, 0.5h; (i) Cbz-Thr $(t \mathrm{Bu})-\mathrm{OH}, \mathrm{EDC}, \mathrm{HOBt}, \mathrm{NMM}, \mathrm{DCM}, \mathrm{rt}, 2 \mathrm{~h} ;(\mathrm{j}) \mathrm{LiBH} 4, \mathrm{THF}, 0{ }^{\circ} \mathrm{C} \rightarrow \mathrm{rt}$, $2 \mathrm{~h}$; (k) $\mathrm{Et}_{3} \mathrm{~N}$, DMSO, $15{ }^{\circ} \mathrm{C}$, then $\mathrm{SO}_{3}-$ Pyridine, $15{ }^{\circ} \mathrm{C} \rightarrow \mathrm{rt}, 1 \mathrm{~h}$.

tion $=1.93 \AA$ ) is shown in Figure 1A. Related parameters for $\mathrm{X}$-ray data collection and refinements are listed in Table 2. The active site consists of a Cys145-His41 catalytic dyad at the $\mathrm{S}^{\prime}$ ' pocket, an oxyanion hole formed by the aldehyde oxygen and N-H of Cys145 and Gly143 at the S1 pocket, and a large hydrophobic cavity at the S2 to S4 pockets. The inhibitor exhibits a unique and unsymmetrical binding mode (Figure 1B) with the covalent bond, and most of the hydrogen bond interactions ( 7 out of 10 in total) gathered near the P1 site and the aldehyde acceptor, whereas numerous hydrophobic interactions are grouped in the P2, P3, and P4 sites. At the acceptor site, Cys145 attacks the carbonyl group of the aldehyde to form a covalent $\mathrm{C}-\mathrm{S}$ bond (bond length $=1.24 \AA$ ) and induces the formation of two hydrogen bonds between the aldehyde oxygen 

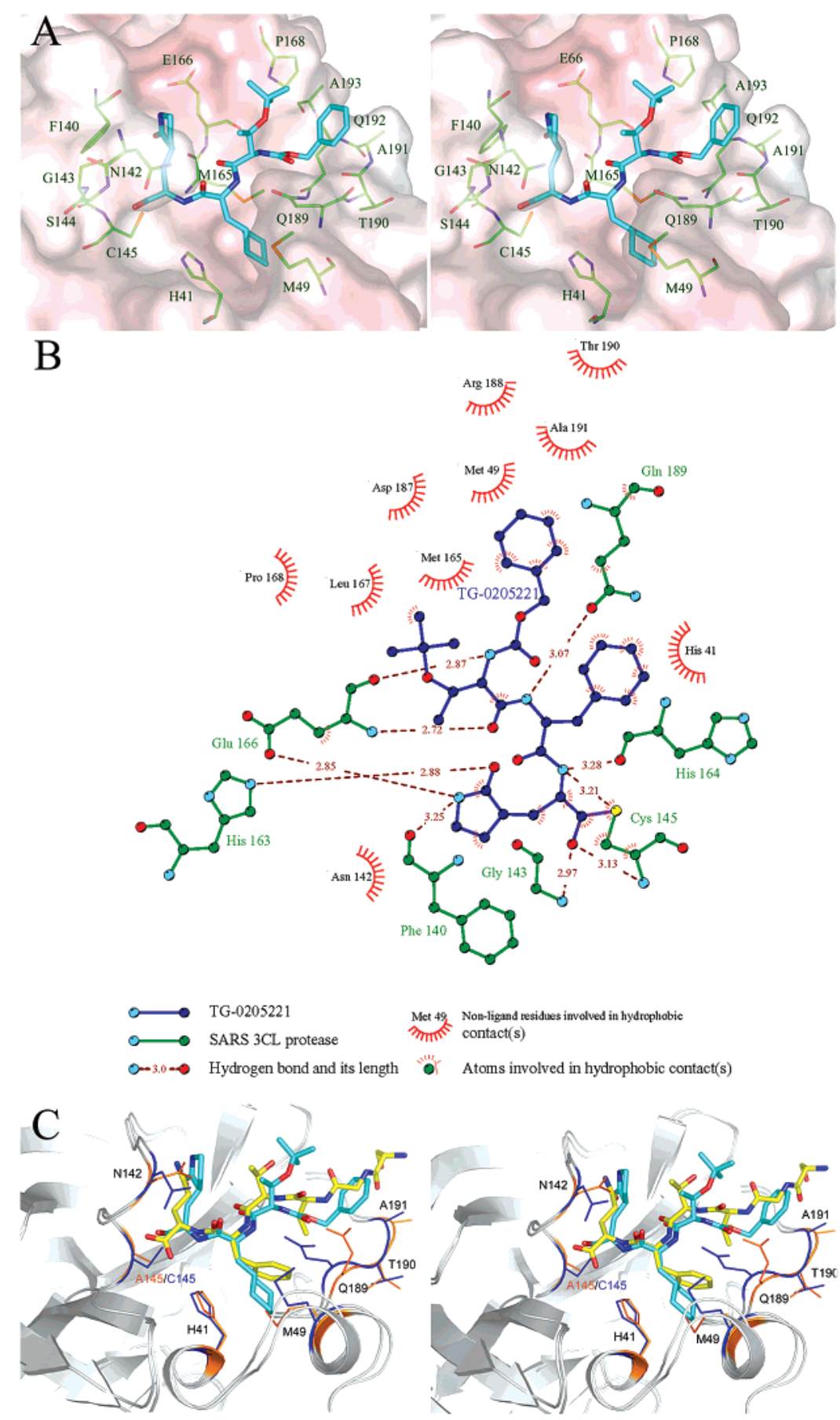

Figure 1. (A) Stereoview of the SARS 3CL protease bound with the TG-0205221 (15) inhibitor shown by electrostatic potential. TG-0205221 (cyan stick) is fitted into the active site pocket of $3 \mathrm{CL}^{\text {pro }}$, and the surrounding residues of $3 \mathrm{CL}^{\text {pro }}$ are shown as green lines. (B) Interactions between SARS 3CL pro and TG-0205221. Schematic representation of key contacts between TG-0205221 and 3CL pro. The covalent bond between the S atom of C145 and the carbon atom of the P1' aldehyde group of TG-0205221 is shown by a purple line. The diagram was generated with LIGPLOT. ${ }^{23}$

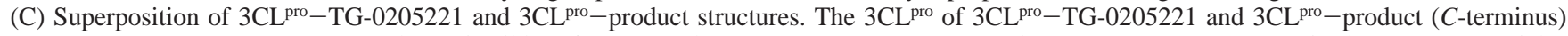
(SGVTFQ) complex structures are shown in ribbon format. In the 3CL pro-TG-0205221 complex structure, TG-0205221 is shown as cyan sticks, and the residues with conformational change are shown by blue lines. In the $3 \mathrm{CL}^{\text {pro }}$-product structure, the product is shown by yellow sticks, and the residues with conformational change are shown by orange lines.

and the N-H of Gly143 and Cys145 itself (Figure 1B). The fivemember lactam ring on P1 forms three hydrogen bonds with His163, Phe140, and Glu166 as well as hydrophobic contacts with the S1 environment.

Unlike P1, interacting mainly with hydrogen bonds, the P2 site forms extensive hydrophobic contacts with its environment. As shown in Figure 1B, most of the cyclohexyl carbon atoms (5 out of 6 in total) are involved in hydrophobic interactions. The peptide backbone of $\mathrm{P} 2-\mathrm{P} 4$ residues also forms three hydrogen bonds by the N-H on P2 with the oxygen on Gln189 and the oxygen on $\mathrm{P} 3$ with the $\mathrm{N}-\mathrm{H}$ on Glu166 as well as the $\mathrm{N}-\mathrm{H}$ on P3 with the oxygen on Glu166. These hydrogen bonds also contribute to the strong interactions of TG-0205221 with the enzyme.

Because of the much easier synthetic procedures and very similar properties of structure, enzyme, and cell activity against $3 \mathrm{C}$ protease in comparison with those of AG7088, ${ }^{12 a, 13}$ we selected compound $\mathbf{1}$ as the reference compound for our project. 
Table 2. X-ray Data Collection and Refinement Statistics of SARS 3CL ${ }^{\text {pro-TG-0205221 Complex }}$

\begin{tabular}{|c|c|}
\hline \multicolumn{2}{|c|}{ Data Collection } \\
\hline space group & \multirow[t]{2}{*}{$C 2$} \\
\hline cell dimensions & \\
\hline$a, b, c(\AA)$ & $109.0,81.2,53.3$ \\
\hline$\beta\left({ }^{\circ}\right)$ & 104.7 \\
\hline resolution $(\AA)^{a}$ & $50.0-1.93(2.00-1.93)$ \\
\hline$R_{\text {merge }} b$ & $0.052(0.549)$ \\
\hline$I / \sigma(I)$ & $24.87(2.18)$ \\
\hline completeness (\%) & $99.8(99.3)$ \\
\hline redundancy & $4.1(3.6)$ \\
\hline \multicolumn{2}{|c|}{ Refinement Statistics } \\
\hline no. reflections & 28,192 \\
\hline$R_{\text {work }} / R_{\text {free }}{ }^{c}$ & $20.45 / 24.93$ \\
\hline average B-values $\left(\AA^{2}\right)$ & \\
\hline \multicolumn{2}{|l|}{ (no. of atoms) } \\
\hline protein & $38.5(2371)$ \\
\hline water & $47.1(257)$ \\
\hline inhibitor & $33.9(43)$ \\
\hline rmsd from ideal & 0.005 \\
\hline \multicolumn{2}{|l|}{ bond length (å) } \\
\hline rmsd from ideal & 1.45 \\
\hline bond angles $\left({ }^{\circ}\right)$ & \\
\hline
\end{tabular}

${ }^{a}$ Values in parentheses refer to the highest resolution bin. ${ }^{b} R_{\text {merge }}=\Sigma \mid\left(I_{h k l}\right)$ $-<I>\mid / \Sigma\left(I_{h k l}\right)$, where $I_{h k l}$ is the integrated intensity of a given reflection. ${ }^{c} R_{\text {work }}=\left(\Sigma\left|F_{\mathrm{o}}-F_{\mathrm{c}}\right|\right) /\left(\Sigma F_{\mathrm{o}}\right)$, where $F_{\mathrm{o}}$ and $F_{\mathrm{c}}$ are observed and calculated structure factors.

On the basis of the backbone structure of compound 1 (Table 3 ), each site of $\mathrm{P} 1^{\prime}-\mathrm{P} 4$ was modified in a systematic fashion in order to study structure-activity relationships with the enzyme. We have learned that the P1 site favors glutamine type of residues, including glutamine and the five-member lactam ring. ${ }^{13,14} \mathrm{~A}$ five-member lactam ring was found to provide much better enzyme activity ( $>15$-fold) than the ones with glutamine residue (data not shown). The strong binding feature of the fivemember lactam ring is evidenced by the multi-hydrogen-bond formation in the crystal structure (Figure 1B). We then fixed all of the groups from $\mathrm{P} 1$ ' to $\mathrm{P} 3$ and replaced the methyl isoxazole at P4 with a series of small alkyls or aryls and heteroaryls extended with small alkyls for activity screenings. The benzoxy group was found to give a more than 4-fold increase in enzyme activity (Table 3 , compound $\mathbf{1}$ and $\mathbf{2}$ ) and became the best group for this site. As is demonstrated in the crystal structure (Figure 1A), the benzoxy group locks in a unique folding conformation with the methylene group residing in the small corner pocket, whereas the phenyl ring aligns parallel to the wall-shaped area near A191. Strong lipophilic interactions between the benzene ring and its environment are observed by the measured hydrophobic contacts from most of the carbon atoms (4 out of 6 ) on the ring (Figure 1B).

For the P2 site, substituting the phenylalanine or 4-fluorophenylalanine with a leucine group increased enzyme activity by about 4 -fold in our study (Table 3, compound $\mathbf{2}$ and 3). This is probably due to the rigid and planar properties of the phenyl ring, which are not favorable for binding in the $\mathrm{S} 2$ hydrophobic pocket. As is shown in Figure 1C, the cyclohexyl alanine ring

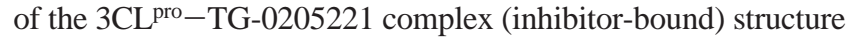
(cyan object) fits deeper into the $\mathrm{S} 2$ pocket in a stable chair form than the rigid phenylalanine of the 3CL ${ }^{\text {pro-product }}$ complex (product-bound) structure (yellow object, SGVTFQ) ${ }^{15}$ The P3 site residue was predicted to have no specificity for binding and may orient toward the bulk solvent ${ }^{12}$ or shift to the P2 site. ${ }^{13}$ However, we found that inserting a lipophilic tertbutyl group at this site further enhances the binding affinity more than 10-fold (Table 3, compound 3 and 4). This enhancement may be explained by the crystal structure in Figure 1A showing that the tert-butyl group shifts to the $\mathrm{P} 4$ site and forms induced hydrophobic interactions with the phenyl ring of the benzoxy group, which is folded and faces P3 by sticking to the methylene group in a small corner pocket near A191 as previously described. Note that the loop region of a.a. 190-194 (Figure 1A), like a pen holder, is holding the end of the P6 site like a pen tip in the product-bound structure (Figure $1 \mathrm{C}$, yellow object) and keeping the backbone away from the bottom of the active site, whereas in the inhibitor-bound structure (Figure 1C, cyan object), the tert-butyl threonine on the P3 forms induced hydrophobic interactions with the $\mathrm{P} 4$ benzene ring by a folded conformation that snugly fits the backbone into the hydrophobic S3 and S4 pockets and stabilizes the three hydrogen bond interactions (two with Glu166 and one with Gln189) (Figure 1B). The inhibitor-bound structure (TG-0205221) is found to fit more tightly to the active site pockets by a larger calculated contact area of $1119.79 \AA^{2}$ than the product-bound structure (SGVTFQ) (1050.95 $\left.\AA^{2}\right)$.

In addition to enzyme activity, we further focused on the issues of cell activity, stability, and other drug-like properties. On the basis of the structure of potent compound $4\left(K_{\mathrm{i}}=58\right.$ $\mathrm{nM}$ ), we replaced the leucine residue at P2 with the more lipophilic cyclohexyl alanine to improve the cell activity. This strategy resulted in an enhancement of cell activity for our overall pharmacophore, as is evidenced by the prominent antiviral activity of TG-0205221 described in Table 1 and the next section. Although the $\mathrm{P} 1^{\prime}$ group of the 1,4-Michael acceptor (e.g., $\alpha, \beta$-vinyl ethyl ester, $-\mathrm{CH}=\mathrm{CH}-\mathrm{C}(\mathrm{O})-\mathrm{OEt}$ ) in compounds 1-4 functioned as an efficient center to interact with Cys145 for irreversible binding, such an ethyl ester group is easily hydrolyzed to carboxylic acid by carboxyl esterases present in plasma; for example, AG7088 lost its activity in the plasma of rodents and rabbits. ${ }^{16,17}$ As a result, we replaced the whole vinyl ethyl ester group with another efficient cystine acceptor, aldehyde, for our pharmacophore. As shown in Table 4, TG-0205221 displays quite stable profile in mouse, rat, and human plasma.

Antiviral Activity. To conveniently monitor antiviral activity, we employed a screening system of human coronavirus $\mathrm{HCoV}$ 229E and MRC-5 cells as a surrogate assay. TG-0205221 was found to reduce $\mathrm{HCoV} 229 \mathrm{E}$ viral load from the original value of $6.5 \log \mathrm{TCID}_{50} / \mathrm{mL}$ to $3.0 \log$ at $0.625 \mu \mathrm{M}$ and further down to $1.3 \log$ at $1.25 \mu \mathrm{M}$ (Figure $2 \mathrm{~A}$ ) with an estimated $\mathrm{IC}_{50}=$ $0.14 \mu \mathrm{M}$. These results were further confirmed by a viral plaque reduction assay (Figure 2B) in which MRC-5 cells were infected with a 10 -fold dilution of $\mathrm{HCoV} 229 \mathrm{E}$ viral stock $\left(1.1 \times 10^{6}\right.$ $\mathrm{pfu} / \mathrm{mL})$. The cytopathic effect (CPE) resulting from the viral replication produced visible plaques in the MRC-5 cell layer. TG-0205221 at $1 \mu \mathrm{M}$ (Figure 2C) protected cells from all six viral dilutions, whereas the control plate without drug treatment gave visible plaques even at a $10^{-5}$ dilution of the viral stock.

The experiments of the antiviral activity of TG-0205221 against SARS coronavirus replication in Vero E6 cells were performed in a biosafety level-3 (BSL-3) laboratory at the University of Texas Medical Branch at Galveston (UTMB). TG0205221 reduced the SARS CoV viral titer from 6.7 to 6.4 , 6.0, 5.0, and 2.0 $\log \mathrm{TCID}_{50} / \mathrm{mL}$ at $0.625,1.25,2.5,5.0 \mu \mathrm{M}$, respectively (Figure $3 \mathrm{~A}$ ), with a $4.7 \mathrm{log}$ viral titer reduction at $5 \mu \mathrm{M}$ drug concentration. CPE measurements were also performed with Vero E6 cells infected by SARS CoV (original stock: $1 \times 10^{7} \mathrm{TCID}_{50} / \mathrm{mL}$ ). Partial and complete protections on the cells against SARS CoV by TG-0205221 were observed at 2.5 and $5 \mu \mathrm{M}$, respectively (Figure $3 \mathrm{~B}-\mathrm{E}$ ). 
Table 3. Enzyme and Cell Activity of TG-0205221 Analogues

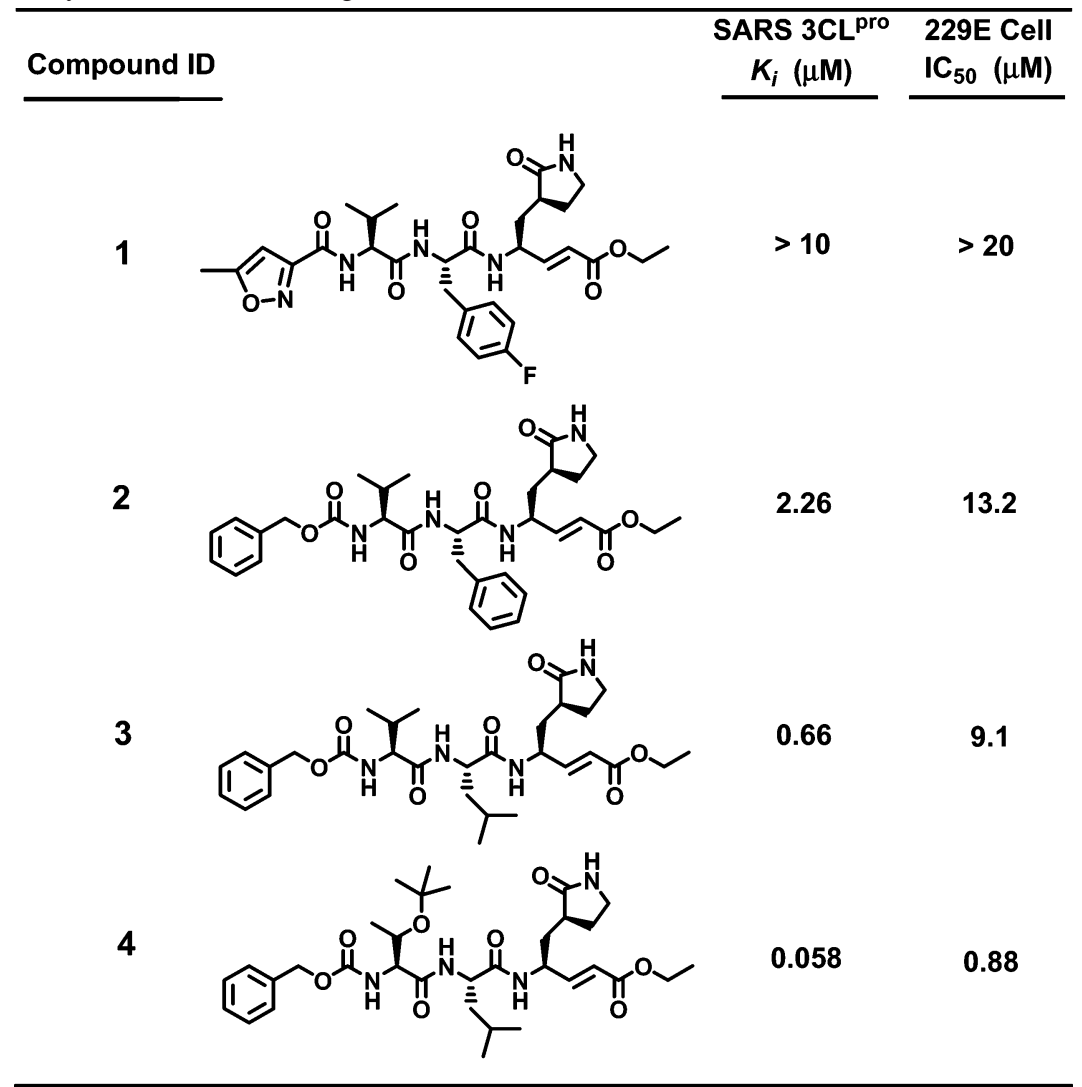

Table 4. Plasma Stability of TG-0205221 ${ }^{a}$

\begin{tabular}{cccr}
\hline \multirow{2}{*}{$\begin{array}{c}\text { incubation } \\
\text { time }(\min )\end{array}$} & rat & mouse & human \\
\cline { 2 - 4 } & $100 \pm 19$ & $100 \pm 6$ & $100 \pm 7$ \\
0 & $70 \pm 1$ & $84 \pm 1$ & $81 \pm 3$ \\
120 & $73 \pm 7$ & $71 \pm 12$ & $83 \pm 7$ \\
\hline
\end{tabular}

${ }^{a}$ The drug was added to $90 \%$ rat, mouse, or human plasma and incubated for 0,30 , and $120 \mathrm{~min}$ in respective wells. The solution was then added to 10 times the volume of acetonitrile for denaturization and analyzed by liquid chromatography/mass spectrometry (LC/MS).

\section{Conclusions}

In summary, we have discovered a potent SARS $3 \mathrm{CL}^{\text {pro }}$ inhibitor that shows promising antiviral activities against SARS coronavirus and human coronavirus HCoV 229E. The resolved crystal structure showed that this inhibitor binds to the enzyme with extensive hydrophobic contacts by the interaction of its 16 carbons with 10 residues on the enzyme. These hydrophobic contacts combine with 10 hydrogen bonds and 1 covalent bond to form a strong binding conformation for this $3 \mathrm{CL}^{\text {pro }}$ inhibitor. The crystal structure has revealed binding characteristics of a SARS inhibitor that are different from early reports ${ }^{13,14}$ and shall provide new understanding for designing inhibitors of other viral proteases with the sequence and/or structure homologous to that of the SARS CoV protease. TG-0205221 and its analogues showed favorable pharmacokinetic profiles in rodents (data not shown). Further testing of the inhibitors in animal disease models is underway. Through the enormous effort of the southeastern Asian health authorities, the spread of SARS CoV in 2002 was effectively brought under control in a short period of time. However, we believe that an antiviral drug, such as TG-0205221, should be developed as a defensive measure against a potential future outbreak of the infection.

\section{Experimental Section}

General Methods. Melting points were obtained on a Buchi B-545 apparatus and are uncorrected. ${ }^{1} \mathrm{H}$ and ${ }^{13} \mathrm{C}$ NMR spectra were recorded on a Varian Mercury Plus 300 spectrometer. Chemical shifts are reported downfield from tetramethylsilane $(=0)$ for ${ }^{1} \mathrm{H}$ NMR. Mass spectra (MS) were determined on an Agilent 1100 series mass spectrometer (ESI-MS). High-Resolution Mass spectra (HR-MS) were determined on a Finnigan MAT 95S. Reagents and solvents were used as obtained from commercial suppliers without further purification. Chromatographic purification of the compounds was performed on silica gel $60(63-200 \mu \mathrm{m})$ purchased from Merck Co. and a Pre-Packed Column Merck KGaA RT 250-25. HPLC was measured by a Waters 2795 system, with a Waters 2996 PDA detector, and an Agilent/ZORBAX Eclipse/XDB-C18/4.6 $\times$ $150 \mathrm{~mm}$ column as well as a Gilson 215 system, with a Gilson UV/Vis-156 detector, and a LiChrospher 100 RP-18e column.

All animal procedures were approved by the Animal Care Committee of TaiGen Biotechnology Co., Ltd.

2-tert-Butoxycarbonylamino-pentanedioic Acid Dimethyl Ester (6). To a stirred suspension of commercially available L-glutamic acid $(50.0 \mathrm{~g}, 340 \mathrm{mmol})$ in dry $\mathrm{MeOH}(1100 \mathrm{~mL}, 0.3 \mathrm{M})$ was added dropwise TMSCl (162 g, $1490 \mathrm{mmol}, 190 \mathrm{~mL}$ ) at $0{ }^{\circ} \mathrm{C}$. After the addition was completed, the reaction was allowed to warm-up to room temperature and stirred until TLC analysis showed no starting material (about $15 \mathrm{~h}$ ). Then, $\mathrm{Et}_{3} \mathrm{~N}$ (222 g, $2190 \mathrm{mmol}, 306 \mathrm{~mL})$ and $(\mathrm{Boc})_{2} \mathrm{O}(82 \mathrm{~g}, 376 \mathrm{mmol})$ were sequentially added at the same temperature. The reaction mixture was stirred until TLC analysis showed completed protection. The solvent was removed under reduced pressure, and the residue was triturated and washed with $\mathrm{Et}_{2} \mathrm{O}$ using a pad of Celite. The combined organic layers were evaporated, and the residue was purified by silica gel column chromatography $(15-20 \%$ EtOAc in $n$-hexane as the eluent) to afford $N$-Boc-L- $(+)$-glutamic acid dimethyl ester $(6,88.0 \mathrm{~g}, 320 \mathrm{mmol})$ in $94 \%$ yield as an oil. ${ }^{1} \mathrm{H}$ NMR $\left(\mathrm{CDCl}_{3}\right) \delta 1.40(9 \mathrm{H}, \mathrm{s}), 1.91(1 \mathrm{H}, \mathrm{m}), 2.14(2 \mathrm{H}, \mathrm{m}), 2.37$ $(2 \mathrm{H}, \mathrm{m}), 3.64(3 \mathrm{H}, \mathrm{s}), 3.70(3 \mathrm{H}, \mathrm{s}), 4.29(1 \mathrm{H}, \mathrm{br} \mathrm{s})$; ESI-MS $(\mathrm{m} / \mathrm{z})$ : $276(\mathrm{M}+\mathrm{H})^{+}$. 

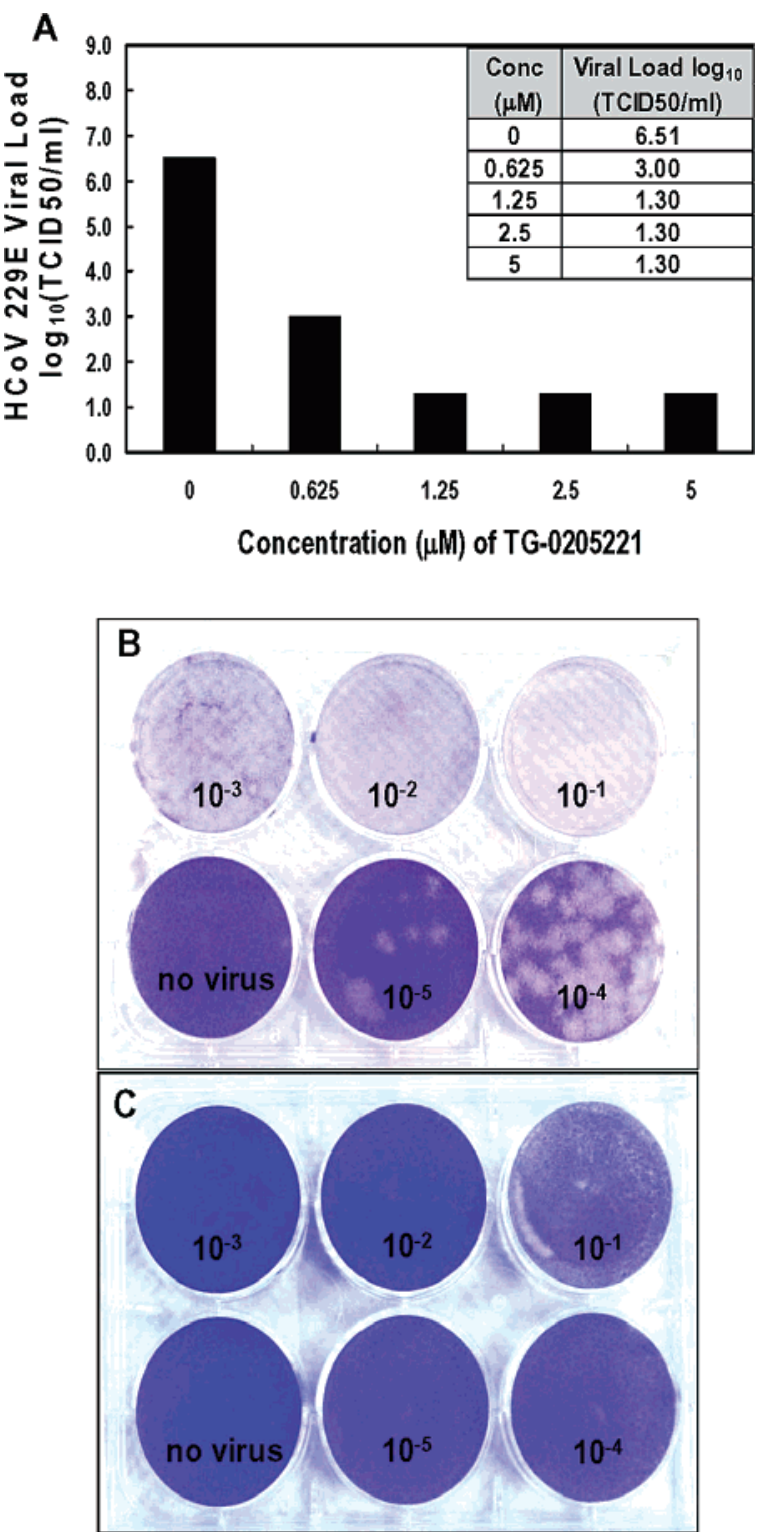

Figure 2. Inhibition of HCoV 229E replication by TG-0205221. (A) Reduction of infectious titers: MRC-5 cells were infected with human coronavirus HCoV 229E, kindly provided by Dr. Michael Lai (Academia Sinica, Taiwan), in the presence or absence of the drug for 72 $\mathrm{h}$. The culture medium was harvested and $\mathrm{TCID}_{50}$ determined by reinfecting a fresh batch of MRC- 5 cells. $\left(\mathrm{TCID}_{50}=50 \%\right.$ tissue culture infective dose. This is the reciprocal of the highest dilution of virus that causes 50\% CPE of the cultured well.) (B) and (C) Plaque reduction assay: A stock virus of $1.1 \times 10^{6} \mathrm{pfu} / \mathrm{mL}$ was serially diluted 10 -fold with D-10, as labeled in each plate, and infected with MRC-5 without the drug (B), or with $1 \mu \mathrm{M}$ drug $(\mathrm{C})(\mathrm{pfu}=$ plaque forming unit). The plates were overlayed with $0.3 \%$ agarose on day 2 and fixed with $10 \%$ formalin and stained with $0.5 \%$ crystal violet on day 6 .

2-tert-Butoxycarbonylamino-4-cyanomethyl-pentanedioic Acid Dimethyl Ester (7). To a solution of $N$-Boc-L- $(+)$-glutamic acid dimethyl ester $(\mathbf{6}, 20 \mathrm{~g}, 72.6 \mathrm{mmol})$ in THF $(50 \mathrm{~mL})$ was added dropwise a solution of LiHMDS (26.3 g, $157 \mathrm{mmol})$ in THF (250 $\mathrm{mL})$ at $-78{ }^{\circ} \mathrm{C}$ under nitrogen atmosphere. The resulting mixture was stirred at $-78{ }^{\circ} \mathrm{C}$ for $1.5 \mathrm{~h}$. Bromoacetonitrile ( $\left.13 \mathrm{~g}, 108 \mathrm{mmol}\right)$ was added dropwise to the dianion solution over a period of $1 \mathrm{~h}$ while maintaining the temperature below $-70{ }^{\circ} \mathrm{C}$. The reaction mixture was further stirred at $-78{ }^{\circ} \mathrm{C}$ until the disappearance of the starting material was confirmed by TLC analysis $(1-2 \mathrm{~h})$.

The reaction was quenched with precooled methanol $(10 \mathrm{~mL})$ in one portion and stirred for $10 \mathrm{~min}$. The resulting methoxide was then quenched with a precooled acetic acid $(9 \mathrm{~mL})$ in THF (60
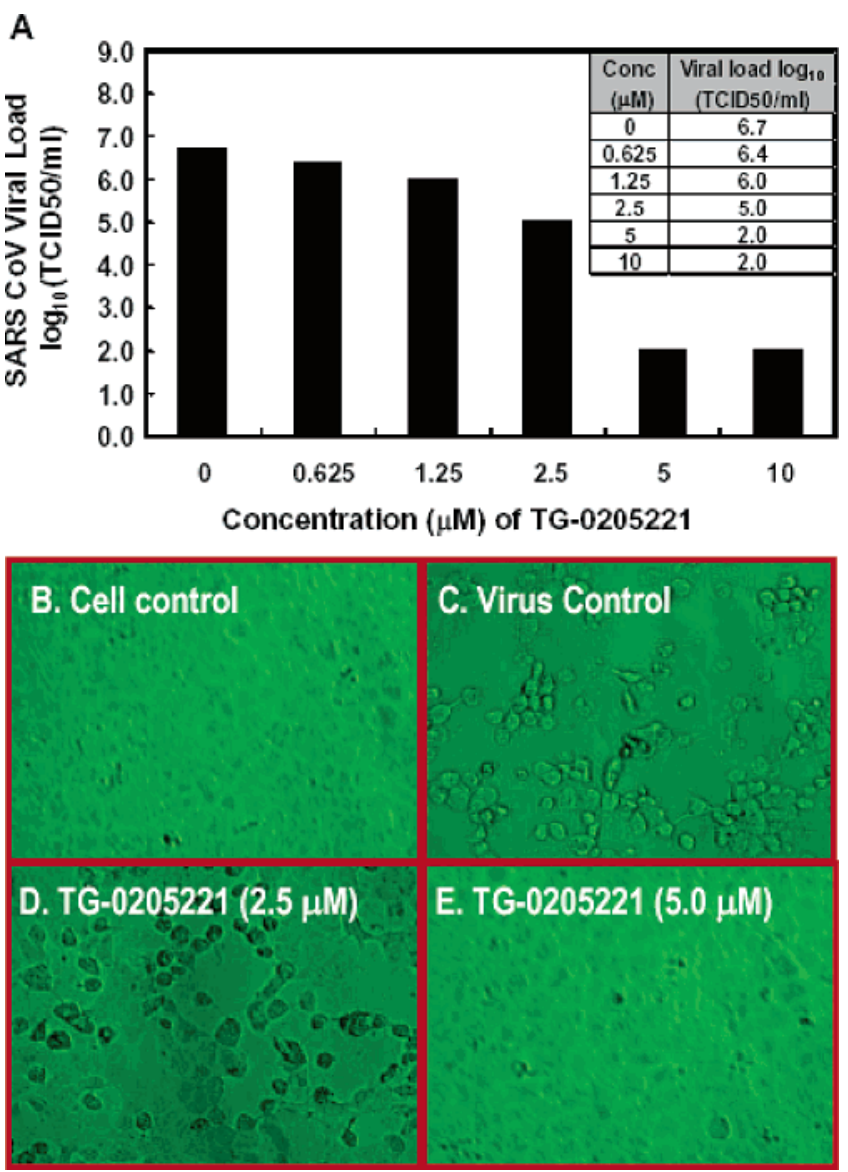

Figure 3. (A) Reduction of infectious titers of SARS-CoV by TG0205221. Vero E6 cells were infected with SARS-CoV in the presence of the drug at the indicated concentrations for $24 \mathrm{~h}$. The culture medium was harvested and TCID $_{50}$ determined by re-infecting a fresh batch of Vero E6 cells. (B)-(E) Prevention of the cytopathic effect (CPE) of SARS-CoV in Vero E6 cells by TG-0205221. Vero E6 cells were cultured in DMEM and 10\% FCS medium (D-10) (B). Then $1 \times 10^{7}$ $\mathrm{TCID}_{50} / \mathrm{mL}$ of stock virus was diluted with $\mathrm{D}-10$. The cells were infected with $100 \mathrm{TCID}_{50}$ per well, or multiplicity of infection (MOI) of $0.001-0.002$, without the presence of the drug (C), with $2.5 \mu \mathrm{M}$ (D), or $5.0 \mu \mathrm{M}$ (E) drug. SARS-CoV usually induced CPE in Vero E6 cells within 2 days. The cells were protected and displayed slight to no $\mathrm{CPE}$ at the drug concentrations. The CPE was observed and scored daily until the experiments were terminated 6 days after infection. The Urbani strain of SARS coronavirus, kindly provided by Dr. T. G. Ksiazek (Centers for Disease Control, Atlanta, Georgia), was used throughout this study. The experiments were conducted in a BSL-3 laboratory at the University of Texas Medical Branch at Galveston (UTMB).

$\mathrm{mL}$ ). After stirred for $10 \mathrm{~min}$, the cooling bath was removed and replaced with a water bath. The reaction mixture was allowed to warm up to $0 \pm 5{ }^{\circ} \mathrm{C}$ and then poured into brine solution $(10 \mathrm{~g}$ of $\mathrm{NaCl}$ in $100 \mathrm{~mL}$ water) in a $1 \mathrm{~L}$ extractor. The aqueous layer was separated, and the organic layer was concentrated to afford a dark brown oil. Silica gel $(25 \mathrm{~g})$ and methylene chloride $(60 \mathrm{~mL})$ were added to the Rotorvap flask and spun on a Rotorvap for $1 \mathrm{~h}$ without heat and in a vacuum. The slurry was then filtered and washed with more methylene chloride $(100 \mathrm{~mL})$. The light brown filtrate was concentrated and purified by silica gel column chromatography (50\% EtOAc in $n$-hexane as the eluent) to afford compound $7(19.0$ $\mathrm{g}, 60.4 \mathrm{mmol})$ in $83 \%$ yield. ${ }^{1} \mathrm{H}$ NMR $\left(\mathrm{CDCl}_{3}\right) \delta 1.42(9 \mathrm{H}, \mathrm{s})$, $2.10-2.17(2 \mathrm{H}, \mathrm{m}), 2.77-2.90(3 \mathrm{H}, \mathrm{m}), 3.73(3 \mathrm{H}, \mathrm{s}), 3.74(3 \mathrm{H}$, $\mathrm{s}), 4.32-4.49(1 \mathrm{H}, \mathrm{m}), 5.12(1 \mathrm{H}, \mathrm{d}, J=6.0 \mathrm{~Hz})$; ESI-MS $(\mathrm{m} / z)$ $315(\mathrm{M}+\mathrm{H})^{+}$

2-tert-Butoxycarbonylamino-3-(2-oxo-pyrrolidin-3-yl)-propionic Acid Methyl Ester (9). Compound 7 (10.0 g, $31.8 \mathrm{mmol}$ ) was dissolved in $\mathrm{AcOH}(240 \mathrm{~mL})$ and shaken with $10 \% \mathrm{Pd} / \mathrm{C}(20$ 
g) under $\mathrm{H}_{2}$ gas $(70 \mathrm{psi}$ ) for $2 \mathrm{~h}$. The mixture was filtered over Celite. The filtrate was evaporated under reduced pressure, and the residue was repeatedly evaporated from methyl tert-butyl ether to yield a light pink solid. Then, the crude compound was dissolved in $\mathrm{THF}$, and $\mathrm{Et}_{3} \mathrm{~N}(20 \mathrm{~mL})$ was added to the solution. The resulting mixture was stirred at $60{ }^{\circ} \mathrm{C}$ overnight. The reaction was quenched with $\mathrm{H}_{2} \mathrm{O}(50 \mathrm{~mL})$. The layers were separated, and the aqueous layer was further extracted with methylene chloride. The organic layers were combined, dried $\left(\mathrm{MgSO}_{4}\right)$, and filtered. The light brown filtrate was concentrated and purified by silica gel column chromatography $(50-100 \%$ EtOAc in $n$-hexane as eluent) to afford compound $9(5.55 \mathrm{~g}, 19.4 \mathrm{mmol})$ in $61 \%$ yield. ${ }^{1} \mathrm{H}$ NMR $\left(\mathrm{CDCl}_{3}\right)$ $\delta 1.41(9 \mathrm{H}, \mathrm{s}), 1.77-1.88(2 \mathrm{H}, \mathrm{m}), 2.06-2.15(1 \mathrm{H}, \mathrm{m}), 2.39-$ $2.49(2 \mathrm{H}, \mathrm{m}), 3.30-3.35(2 \mathrm{H}, \mathrm{m}), 3.71(3 \mathrm{H}, \mathrm{s}), 4.25-4.33(1 \mathrm{H}$, $\mathrm{m}), 5.49(1 \mathrm{H}, \mathrm{d}, J=7.8 \mathrm{~Hz}), 6.00(1 \mathrm{H}, \mathrm{s}) ;{ }^{13} \mathrm{C}$ NMR $(75 \mathrm{MHz}$, $\left.\mathrm{CDCl}_{3}\right) \delta 28.31,28.48,34.30,38.32,40.55,52.47,52.57,80.08$, 155.96, 173.13, 179.92; ESI-MS $(\mathrm{m} / \mathrm{z}): 287(\mathrm{M}+\mathrm{H})^{+}$.

2-(2-tert-Butoxycarbonylamino-3-cyclohexyl-propionylamino)3-(2-oxo-pyrrolidin-3-yl)-propionic Acid Methyl Ester (11). (a) A commercially available solution of $\mathrm{HCl}$ in 1,4-dioxane $(4.0 \mathrm{M}$, $3.5 \mathrm{~mL})$ was added to compound $9(0.404 \mathrm{~g}, 1.41 \mathrm{mmol})$ and stirred at room temperature for $30 \mathrm{~min}$. The resulting solution was concentrated to remove 1,4-dioxane under vacuum. $\mathrm{CH}_{2} \mathrm{Cl}_{2}(10 \mathrm{~mL})$ was then added to the residue and cooled to $0-5{ }^{\circ} \mathrm{C}$. $N$ Methylmorpholine $(0.62 \mathrm{~mL}, 5.64 \mathrm{mmol})$ was added and stirred for $10 \mathrm{~min}$. (b) In the meantime, 2-tert-butoxycarbonylamino- $(S)$ 3-cyclohexyl-propionic acid $(0.383 \mathrm{~g}, 1.41 \mathrm{mmol})$ was mixed with EDC (0.324 g, $1.69 \mathrm{mmol})$, and HOBt (0.229 g, $1.69 \mathrm{mmol})$ in $\mathrm{CH}_{2} \mathrm{Cl}_{2}(4 \mathrm{~mL})$ and stirred for $20 \mathrm{~min}$.

Solution (a) was then added to solution (b) and stirred at room temperature for $2 \mathrm{~h}$. The reaction mixture was mixed with brine $(10 \mathrm{~mL})$ and extracted with $\mathrm{CH}_{2} \mathrm{Cl}_{2}(3 \times 10 \mathrm{~mL})$. The organic layers were combined and dried with $\mathrm{MgSO}_{4}$ and concentrated. Purification of the residue by flash column chromatography $(3 \% \mathrm{MeOH}$ in $\mathrm{CH}_{2} \mathrm{Cl}_{2}$ as eluent) afforded a white solid of 11 (0.576 g, 1.31 mmol) in $93 \%$ yield. ${ }^{1} \mathrm{H} \mathrm{NMR}\left(\mathrm{CDCl}_{3}\right) \delta 0.85-0.99(2 \mathrm{H}, \mathrm{m}), 1.12-$ $1.24(4 \mathrm{H}, \mathrm{m}), 1.41(9 \mathrm{H}, \mathrm{s}), 1.60-1.69(5 \mathrm{H}, \mathrm{m}), 1.76-1.90(3 \mathrm{H}$, $\mathrm{m}), 2.12-2.21(1 \mathrm{H}, \mathrm{m}), 2.37-2.46(2 \mathrm{H}, \mathrm{m}), 3.29-3.37(3 \mathrm{H}, \mathrm{m})$, $3.70(3 \mathrm{H}, \mathrm{s}), 4.17-4.25(1 \mathrm{H}, \mathrm{m}), 4.48-4.55(1 \mathrm{H}, \mathrm{m}), 5.00(1 \mathrm{H}, \mathrm{d}$, $J=7.8 \mathrm{~Hz}), 6.44(1 \mathrm{H}, \mathrm{s}), 7.50(1 \mathrm{H}, \mathrm{d}, J=6.9 \mathrm{~Hz}) ;{ }^{13} \mathrm{C}$ NMR $(75$ $\left.\mathrm{MHz} \mathrm{CDCl}_{3}\right) \delta 26.28,26.43,26.60,28.30,28.46,32.84,33.42$, $33.78,34.14,38.42$, 40.60, 40.84, 51.21, 52.50, 79.92, 155.78, 172.40, 173.51, 179.97; ESI-MS $(\mathrm{m} / \mathrm{z}): 462(\mathrm{M}+\mathrm{Na})^{+}$.

2-[2-(2-Benzyloxycarbonylamino-3-tert-butoxy-butyrylamino)3-cyclohexyl-propionylamino]-3-(2-oxo-pyrrolidin-3-yl)-propionic Acid Methyl Ester (13). (a) A commercially available solution of $\mathrm{HCl}$ in 1,4-dioxane $(4.0 \mathrm{M}, 2.5 \mathrm{~mL})$ was added to compound $\mathbf{1 1}$ $(0.443 \mathrm{~g}, 1.01 \mathrm{mmol})$ and stirred at room temperature for $30 \mathrm{~min}$. The resulting solution was concentrated to remove 1,4-dioxane under vacuum. $\mathrm{CH}_{2} \mathrm{Cl}_{2}(10 \mathrm{~mL})$ was then added to the residue and cooled to $0-5{ }^{\circ} \mathrm{C}$, followed by the addition of $N$-methylmorpholine (0.409 g, $0.45 \mathrm{~mL}, 4.04 \mathrm{mmol})$ and stirred for $10 \mathrm{~min}$. (b) In the meantime, 2-benzyloxycarbonylamino- $(S)$-3-tert-butoxy-butyric acid $(0.325 \mathrm{~g}, 1.05 \mathrm{mmol})$ was mixed with EDC $(0.232 \mathrm{~g}, 1.21 \mathrm{mmol})$ and HOBt $(0.164 \mathrm{~g}, 1.21 \mathrm{mmol})$ in $\mathrm{CH}_{2} \mathrm{Cl}_{2}(4 \mathrm{~mL})$ and stirred for $20 \mathrm{~min}$.

Solution (a) was then added to solution (b) and stirred at room temperature for $2 \mathrm{~h}$. The reaction residue was added to brine (10 $\mathrm{mL})$ and extracted with $\mathrm{CH}_{2} \mathrm{Cl}_{2}(3 \times 10 \mathrm{~mL})$. The organic layers were combined and dried with $\mathrm{MgSO}_{4}$ and concentrated. Purification of the residue by flash column chromatography $(3 \% \mathrm{MeOH}$ in $\mathrm{CH}_{2} \mathrm{Cl}_{2}$ as eluent) provided a white solid $(13,0.408 \mathrm{~g}, 64 \%) .{ }^{1} \mathrm{H}$ NMR $\left(\mathrm{CDCl}_{3}\right) \delta 0.83-1.00(2 \mathrm{H}, \mathrm{m}), 1.06(3 \mathrm{H}, \mathrm{d}, J=6.0 \mathrm{~Hz})$, $1.13-1.20(3 \mathrm{H}, \mathrm{m}), 1.25(9 \mathrm{H}, \mathrm{s}), 1.34(1 \mathrm{H}, \mathrm{m}), 1.47-1.90(9 \mathrm{H}$, m), $2.15(1 \mathrm{H}, \mathrm{m}), 2.37(2 \mathrm{H}, \mathrm{m}), 3.27-3.30(2 \mathrm{H}, \mathrm{m}), 3.70(3 \mathrm{H}, \mathrm{s})$, $4.15-4.17(2 \mathrm{H}, \mathrm{m}), 4.40(1 \mathrm{H}, \mathrm{dd}, J=13.5 \mathrm{~Hz}, 8.1 \mathrm{~Hz}), 4.51(1 \mathrm{H}$, m), $5.06(1 \mathrm{H}, A \mathrm{~B}$ quartet, $J=12.3 \mathrm{~Hz}), 5.12(1 \mathrm{H}, A \mathrm{~B}$ quartet, $J=$ $12.3 \mathrm{~Hz}), 5.87(2 \mathrm{H}, \mathrm{m}), 7.28-7.35(5 \mathrm{H}, \mathrm{m}), 7.41(1 \mathrm{H}, \mathrm{d}, J=7.8$ $\mathrm{Hz}), 7.58(1 \mathrm{H}, \mathrm{d}, J=6.9 \mathrm{~Hz}) ;{ }^{13} \mathrm{C}$ NMR $\left(75 \mathrm{MHz}, \mathrm{CDCl}_{3}\right) \delta 17.40$, 26.21, 26.36, 26.54, 28.25, 28.39, 32.88, 33.23, 33.72, 34.20, 38.34, $40.28,40.63,51.18,51.53,52.49,59.08,66.94,67.11,75.52$,
$128.22,128.36,128.71,136.36,156.35,169.68,172.29,172.41$, 179.89; ESI-MS $(\mathrm{m} / \mathrm{z}): 631(\mathrm{M}+\mathrm{H})^{+}$.

(2-tert-Butoxy-1-\{2-cyclohexyl-1-[2-hydroxy-1-(2-oxo-pyrrolidin-3-ylmethyl)-ethylcarbamoyl]-ethylcarbamoyl\}-propyl)-carbamic Acid Benzyl Ester (14). To a stirring solution of compound $13(0.450 \mathrm{~g}, 0.713 \mathrm{mmol})$ in THF $(4.7 \mathrm{~mL})$ was added $\mathrm{LiBH}_{4}(2.0$ $\mathrm{M}$ in THF, $1.8 \mathrm{~mL}, 3.6 \mathrm{mmol}$ ) in several portions at $0{ }^{\circ} \mathrm{C}$ under a nitrogen atmosphere. The reaction mixture was stirred at $0{ }^{\circ} \mathrm{C}$ for $1 \mathrm{~h}$, then allowed to warm up to room temperature, and stirred for an additional $2 \mathrm{~h}$. The reaction was quenched by the dropwise addition of $1.0 \mathrm{M} \mathrm{HCl}_{(\mathrm{aq})}(3.6 \mathrm{~mL})$ with cooling in an ice bath. The solution was diluted with ethyl acetate $(11.7 \mathrm{~mL})$ and $\mathrm{H}_{2} \mathrm{O}$ $(5.8 \mathrm{~mL})$. The phases were separated, and the aqueous layer was extracted with ethyl acetate $(3 \times 35 \mathrm{~mL})$. The organic phases were combined together, dried over $\mathrm{MgSO}_{4}$, filtered, and concentrated on a rotorvap to give a yellow oily residue. Column chromatographic purification of the residue $\left(6 \% \mathrm{MeOH}\right.$ in $\mathrm{CH}_{2} \mathrm{Cl}_{2}$ as the eluent) afforded a white solid $(\mathbf{1 4}, 0.318 \mathrm{~g}, 74 \%) .{ }^{1} \mathrm{H} \mathrm{NMR}\left(\mathrm{CDCl}_{3}\right)$ $\delta 0.85-0.98(2 \mathrm{H}, \mathrm{m}), 1.07(3 \mathrm{H}, \mathrm{d}, J=6.6 \mathrm{~Hz}), 1.11-1.38(4 \mathrm{H}$, m), $1.24(9 \mathrm{H}, \mathrm{s}), 1.45-1.84(9 \mathrm{H}, \mathrm{m}), 2.00(1 \mathrm{H}, \mathrm{m}), 2.36-2.42$ $(2 \mathrm{H}, \mathrm{m}), 3.26-3.29(2 \mathrm{H}, \mathrm{m}), 3.49-3.59(3 \mathrm{H}, \mathrm{m}), 3.98(1 \mathrm{H}, \mathrm{m})$, $4.13-4.18(2 \mathrm{H}, \mathrm{m}), 4.35(1 \mathrm{H}, \mathrm{m}), 5.06(1 \mathrm{H}, A \mathrm{~B}$ quartet, $J=12.3$ $\mathrm{Hz}), 5.13(1 \mathrm{H}, A \mathrm{~B}$ quartet, $J=12.3 \mathrm{~Hz}), 5.77(1 \mathrm{H}$, br s $), 6.02$ $(1 \mathrm{H}, \mathrm{d}, J=5.1 \mathrm{~Hz}), 7.29-7.36(6 \mathrm{H}, \mathrm{m}), 7.52(1 \mathrm{H}, \mathrm{d}, J=7.5 \mathrm{~Hz})$; ${ }^{13} \mathrm{C}$ NMR $\left(75 \mathrm{MHz}, \mathrm{CDCl}_{3}\right) \delta 17.66,26.21,26.40,26.54,28.43$, 28.57, 32.75, 32.83, 33.79, 34.42, 38.39, 39.97, 40.72, 50.32, 52.05, $59.34,65.86,67.02,67.20,75.60,128.29,128.41,128.76,136.39$, 156.54, 170.03, 172.84, 181.28; ESI-MS $(\mathrm{m} / \mathrm{z}): 603(\mathrm{M}+\mathrm{H})^{+}$

(2-tert-Butoxy-1-\{2-cyclohexyl-1-[1-formyl-2-(2-oxo-pyrrolidin-3-yl)-ethylcarbamoyl]-ethylcarbamoyl\}-propyl)-carbamic Acid Benzyl Ester (15) (TG-0205221). To a solution of compound 14 $(0.125 \mathrm{~g}, 0.207 \mathrm{mmol}, 1$ equiv. $)$ in methylsulfoxide $(1.0 \mathrm{~mL})$ was added triethylamine $(0.1 \mathrm{~mL})$. The resulting solution was cooled to $15{ }^{\circ} \mathrm{C}$ with an ice bath followed by the addition of the sulfur trioxide-pyridine complex ( $0.23 \mathrm{~g}, 3$ equiv). The reaction was removed from the ice bath and stirred at room temperature for $1 \mathrm{~h}$. The reaction was then quenched with saturated brine $(1 \mathrm{~mL})$ and extracted with ethyl acetate $(3 \times 5 \mathrm{~mL})$. The combined organic phases were dried over $\mathrm{MgSO}_{4}$, filtered, and concentrated to afford a pale yellow oil. The oil was purified through chromatography (100\% EtOAc) to provide $\mathbf{1 5}$ as a white solid $(0.037 \mathrm{~g}, 30 \%) ; \mathrm{mp}$ 93.6-95.3 ${ }^{\circ} \mathrm{C} .{ }^{1} \mathrm{H}$ NMR $\left(\mathrm{CDCl}_{3}\right) \delta 0.86-1.31(16 \mathrm{H}, \mathrm{m}), 1.56-$ $2.02(13 \mathrm{H}, \mathrm{m}), 2.41(2 \mathrm{H}, \mathrm{m}), 3.31(2 \mathrm{H}, \mathrm{d}, J=7.8 \mathrm{~Hz}), 4.16(2 \mathrm{H}$, br s), $4.42(2 \mathrm{H}, \mathrm{m}), 5.09(2 \mathrm{H}, \mathrm{dd}, J=20,12 \mathrm{~Hz}), 5.89(1 \mathrm{H}, \mathrm{br} \mathrm{s})$, $7.33(5 \mathrm{H}, \mathrm{m}), 7.40(1 \mathrm{H}, \mathrm{d}, J=7.24 \mathrm{~Hz}), 8.01(1 \mathrm{H}, \mathrm{br} \mathrm{s}), 9.48(1 \mathrm{H}$, s); ${ }^{13} \mathrm{C} \mathrm{NMR}\left(75 \mathrm{MHz}, \mathrm{CDCl}_{3}\right) \delta 17.57,26.20,26.40,26.56,28.45$, $28.78,30.00,32.84,33.85,34.43,38.02$, 40.17, 40.66, 51.71, 57.74, $59.22,66.96,67.22,75.61,128.30,128.45,128.78,136.39,156.46$, 169.91, 173.09, 180.03, 199.72; ESI-MS $(\mathrm{m} / \mathrm{z}): 601(\mathrm{M}+\mathrm{H})^{+}$; HRMS (EI) m/z: $\mathrm{C}_{32} \mathrm{H}_{48} \mathrm{~N}_{4} \mathrm{O}_{7}$ (M), calcd., 600.3518; found 600.3542 .

4-(3-(4-Fluoro-phenyl)-2-\{3-methyl-2-[(5-methyl-isoxazole-3carbonyl)-amino]-butyrylamino $\}$-propionylamino)-5-(2-oxo-pyrrolidin-3-yl)-pent-2-enoic Acid Ethyl Ester (1). Compound 1 was prepared by using a procedure similar to that described in the published literature; ${ }^{12(a),(c)} \mathrm{mp} 143-144{ }^{\circ} \mathrm{C} .{ }^{1} \mathrm{H}$ NMR $\left(\mathrm{CDCl}_{3}\right) \delta 0.92$ $(6 \mathrm{H}, \mathrm{t}, J=6 \mathrm{~Hz}), 1.28(3 \mathrm{H}, \mathrm{t}, J=6.9 \mathrm{~Hz}), 1.53-1.59(1 \mathrm{H}, \mathrm{m})$, $1.74-1.81(1 \mathrm{H}, \mathrm{m}), 1.84-1.96(1 \mathrm{H}, \mathrm{m}), 2.11-2.38(3 \mathrm{H}, \mathrm{m}), 2.48$ $(3 \mathrm{H}, \mathrm{s}), 3.02-3.04(5 \mathrm{H}, \mathrm{m}), 3.30-3.36(2 \mathrm{H}, \mathrm{m}), 4.17(2 \mathrm{H}, \mathrm{q}, J=$ $6.9 \mathrm{~Hz}), 4.34(1 \mathrm{H}, \mathrm{t}, J=7.8 \mathrm{~Hz}), 4.53-4.54(1 \mathrm{H}, \mathrm{m}), 4.86(1 \mathrm{H}$, $A$ B quartet, $J=12.3 \mathrm{~Hz}), 5.70(1 \mathrm{H}, \mathrm{d}, J=15.9 \mathrm{~Hz}), 6.41(1 \mathrm{H}, \mathrm{s})$, 6.68-6.75 (2H, m), $6.88(2 \mathrm{H}, \mathrm{m}), 7.10-7.15(2 \mathrm{H}, \mathrm{m}), 7.29-7.32$ $(1 \mathrm{H}, \mathrm{m}), 7.75(1 \mathrm{H}, \mathrm{d}, J=8.1 \mathrm{~Hz}) ;{ }^{13} \mathrm{C} \mathrm{NMR}\left(75 \mathrm{MHz}, \mathrm{CDCl}_{3}\right)$ $\delta 12.55,14.41,18.42,19.41,28.42,31.06,35.20,37.94,38.60$, $41.12,49.04,54.52,59.15,60.76,101.62,115.33,115.62,121.42$, $131.20,131.30,132.24,146.96,158.40,159.62,160.45,163.68$, $166.39,170.63,171.0,171.67,180.58$; ESI-MS $(\mathrm{m} / \mathrm{z}): 600(\mathrm{M}+$ $\mathrm{H})^{+}$; HRMS (EI) $m / z: \mathrm{C}_{30} \mathrm{H}_{38} \mathrm{FN}_{5} \mathrm{O}_{7}(\mathrm{M})$, calcd., 599.2750; found 599.2770.

4-[2-(2-Benzyloxycarbonylamino-3-methyl-butyrylamino)-3phenyl-propionylamino]-5-(2-oxo-pyrrolidin-3-yl)-pent-2-enoic Acid Ethyl Ester (2). Compound 2 was prepared by using a 
procedure similar to that used for compound $\mathbf{1}$ by replacing 5-methyl-isoxazole-3-carbonyl chloride with benzyl chloroformate and (S)-2-amino-3-(4-fluoro-phenyl)-propionic acid with (S)-2amino-3-phenyl-propionic acid; mp $126-132{ }^{\circ} \mathrm{C} .{ }^{1} \mathrm{H}$ NMR $\left(\mathrm{CDCl}_{3}\right)$ $\delta 0.83(3 \mathrm{H}, \mathrm{d}, J=6.6 \mathrm{~Hz}), 0.88(3 \mathrm{H}, \mathrm{d}, J=6.9 \mathrm{~Hz}), 1.27(3 \mathrm{H}, \mathrm{t}$, $J=7.2 \mathrm{~Hz}), 1.46-1.54(1 \mathrm{H}, \mathrm{m}), 1.65-1.78(1 \mathrm{H}, \mathrm{m}), 1.83-1.94$ $(1 \mathrm{H}, \mathrm{m}), 1.99-2.01(1 \mathrm{H}, \mathrm{m}), 2.12-2.22(1 \mathrm{H}, \mathrm{m}), 2.26-2.30(1 \mathrm{H}$, m), $2.80(1 \mathrm{H}, \mathrm{b}), 3.05(2 \mathrm{H}, \mathrm{d}, J=6.3 \mathrm{~Hz}), 3.21-3.30(2 \mathrm{H}, \mathrm{m})$, $3.95(1 \mathrm{H}, \mathrm{t}, J=7.2 \mathrm{~Hz}), 4.16(2 \mathrm{H}, \mathrm{q}, J=6.9 \mathrm{~Hz}), 4.53(1 \mathrm{H}, \mathrm{m})$, $5.08(2 \mathrm{H}, A B$ quartet, $J=12.3 \mathrm{~Hz}), 5.45(1 \mathrm{H}, \mathrm{d}, J=8.4 \mathrm{~Hz}), 5.72$ $(1 \mathrm{H}, \mathrm{d}, J=15.3 \mathrm{~Hz}), 6.54(1 \mathrm{H}, \mathrm{b}), 6.70(1 \mathrm{H}, \mathrm{dd}, J=16.5 \mathrm{~Hz}, 5.4$ $\mathrm{Hz}), 7.15-7.34(10 \mathrm{H}, \mathrm{m}), 7.57(1 \mathrm{H}, \mathrm{d}, J=7.5 \mathrm{~Hz}) ;{ }^{13} \mathrm{C}$ NMR $(75$ $\left.\mathrm{MHz}, \mathrm{CDCl}_{3}\right) \delta 14.45,18.03,19.38,28.41,31.04,35.28,38.53$, $38.63,41.25,49.05,54.61,60.68,61.00,121.52,127.121,128.24$, $128.43,128.72,128.78,129.55,129.72,136.42,136.55,146.89$, $156.81,166.39,171.09,171.49,180.76$; ESI-MS $(\mathrm{m} / \mathrm{z}): 607(\mathrm{M}+$ $\mathrm{H})^{+}$; HRMS (EI) $m / z: \mathrm{C}_{33} \mathrm{H}_{42} \mathrm{~N}_{4} \mathrm{O}_{7}(\mathrm{M})$, calcd. 606.3048; found 606.3070 .

4-[2-(2-Benzyloxycarbonylamino-3-methyl-butyrylamino)-4methyl-pentanoylamino]-5-(2-0xo-pyrrolidin-3-yl)-pent-2-enoic Acid Ethyl Ester (3). A procedure similar to that used for compound 2 was used to prepare this compound (3) by replacing (S)-2-amino-3-phenyl-propionic acid with $(S)$-2-amino-4-methylpentanoic acid; mp $156-163{ }^{\circ} \mathrm{C} .{ }^{1} \mathrm{H} \mathrm{NMR}\left(\mathrm{CDCl}_{3}\right) \delta 0.838(12 \mathrm{H}$, $\mathrm{m}), 1.24(3 \mathrm{H}, \mathrm{t}, J=7.2 \mathrm{~Hz}), 1.46-1.59(4 \mathrm{H}, \mathrm{m}), 1.70-1.76(1 \mathrm{H}$, $\mathrm{m}), 1.99-2.10(2 \mathrm{H}, \mathrm{m}), 2.31-2.37(2 \mathrm{H}, \mathrm{m}), 3.28-3.31(2 \mathrm{H}, \mathrm{m})$, $3.97(1 \mathrm{H}, \mathrm{t}, J=6.9 \mathrm{~Hz}), 4.14(2 \mathrm{H}, \mathrm{q}, J=7.2 \mathrm{~Hz}), 4.59(2 \mathrm{H}, \mathrm{m})$, $5.06(2 \mathrm{H}, \mathrm{s}), 5.54-5.57(1 \mathrm{H}, \mathrm{m}), 5.90(1 \mathrm{H}, \mathrm{d}, J=15.6 \mathrm{~Hz}), 6.81$ $(1 \mathrm{H}, \mathrm{dd}, J=15.3 \mathrm{~Hz}, 4.8 \mathrm{~Hz}), 7.31(5 \mathrm{H}, \mathrm{b}), 7.80(1 \mathrm{H}, \mathrm{d}, J=7.8$ $\mathrm{Hz}) ;{ }^{13} \mathrm{C}$ NMR $\left(75 \mathrm{MHz}, \mathrm{CDCl}_{3}\right) \delta 14.42,18.10,19.42,22.09$, 23.15, 25.09, 28.28, 31.16, 35.48, 38.70, 41.20, 41.92, 48.79, 52.26, $60.71,60.94,67.35,121.55,128.20,128.42,128.77,136.40,147.22$, $156.84,166.42,171.64,172.62,180.79$; ESI-MS $(\mathrm{m} / \mathrm{z}): 573(\mathrm{M}+$ $\mathrm{H})^{+}$; HRMS (EI) $m / z: \mathrm{C}_{30} \mathrm{H}_{44} \mathrm{~N}_{4} \mathrm{O}_{7}(\mathrm{M})$, calcd. 572.3205; found 572.3221 .

4-[2-(2-Benzyloxycarbonylamino-3-tert-butoxy-butyrylamino)4-methyl-pentanoylamino]-5-(2-oxo-pyrrolidin-3-yl)-pent-2-enoic Acid Ethyl Ester (4). Replacing (S)-2-amino-3-methyl-butyric acid with (S)-2-amino-3-tert-butoxy-butyric acid and following the procedure used for 3 afforded compound 4 ; mp $63-65{ }^{\circ} \mathrm{C} .{ }^{1} \mathrm{H}$ $\mathrm{NMR}\left(\mathrm{CDCl}_{3}\right) \delta 0.90-0.95(6 \mathrm{H}, \mathrm{m}), 1.02-1.04(3 \mathrm{H}, \mathrm{m}), 1.22-$ $1.26(12 \mathrm{H}, \mathrm{m}), 1.50-1.66(4 \mathrm{H}, \mathrm{m}), 1.70-2.07(2 \mathrm{H}, \mathrm{m}), 2.31-$ $2.44(3 \mathrm{H}, \mathrm{m}), 3.25-3.31(2 \mathrm{H}, \mathrm{m}), 5.03-5.13(4 \mathrm{H}, \mathrm{m}), 4.46-4.47$ $(1 \mathrm{H}, \mathrm{m}), 4.57-4.58(1 \mathrm{H}, \mathrm{m}), 5.08(2 \mathrm{H}, \mathrm{m}), 5.90(2 \mathrm{H}, \mathrm{d}, J=15.6$ $\mathrm{Hz}), 6.36(1 \mathrm{H}, \mathrm{m}), 6.81(1 \mathrm{H}, \mathrm{dd}, J=15.3 \mathrm{~Hz}, 5.1 \mathrm{~Hz}), 7.29-7.40$ $(6 \mathrm{H}, \mathrm{m}), 7.66(1 \mathrm{H}, \mathrm{d}, J=6.6 \mathrm{~Hz}) ;{ }^{13} \mathrm{C} \mathrm{NMR}\left(75 \mathrm{MHz}, \mathrm{CDCl}_{3}\right)$ $\delta 14.43,17.67,22.19,23.18,25.15,28.46,35.45,38.61,41.42$, $41.63,48.90,52.53,59.29,60.71,67.01,67.27,75.67,76.81,77.44$, $121.67,128.34,128.48,128.80,136.37,147.21,156.44,166.41$, 170.06, 172.25, 180.91; ESI-MS $(\mathrm{m} / \mathrm{z}) 631(\mathrm{M}+\mathrm{H})^{+}$; HRMS (EI) m/z: $\mathrm{C}_{33} \mathrm{H}_{50} \mathrm{~N}_{4} \mathrm{O}_{8}(\mathrm{M})$, calcd. 630.3623; found 630.3596 .

Plasma Stability of TG-0205221. Mouse, rat, or human plasma/ well $(90 \mu \mathrm{L})$ was transferred to a 96 deep well plate and preincubated at $37{ }^{\circ} \mathrm{C}$ for $5 \mathrm{~min}$., followed by the addition of 10 $\mu \mathrm{L}(100 \mu \mathrm{M}$ in $1 \%$ DMSO) of test compound to make a $90 \%$ plasma solution at different time points of 0,30 , and $120 \mathrm{~min}$, respectively. The plasma sample was shaken at $400 \mathrm{rpm}$ at $37{ }^{\circ} \mathrm{C}$ for the different reaction times. The sample was then added to 900 $\mu \mathrm{L} /$ well acetonitrile-containing internal standard and shaken at 400 rpm for $5 \mathrm{~min}$. The 96-well plate sample was centrifuged at 3500 $\mathrm{rpm}$ at $10{ }^{\circ} \mathrm{C}$ for $10 \mathrm{~min}$ and $20 \mu \mathrm{L}$ of clear supernatant was transferred $180 \mu \mathrm{L}$ of $\mathrm{H}_{2} \mathrm{O}$ for LC/MS analysis. The sample was diluted to $0.05 \mu \mathrm{M}$, and $50 \mu \mathrm{L}$ was injected into a Waters Alliance $2795 \mathrm{LC} / \mathrm{MS}$ system with a C-18 column by using $5-95 \% \mathrm{MeOH} /$ $\mathrm{H}_{2} \mathrm{O}+0.1 \%$ formic acid as the mobile phase for analysis.

Cloning, Expression, and Purification of SARS 3CL Protease. SARS-CoV 3CL ${ }^{\text {pro }}$ was cloned into pGEX-6p-1 plasmid DNA (Pharmacia) with a Factor Xa cutting site at the upstream of our target gene. GST-tagged protein was purified using a GST column, and after tag cleavage, the mixture was loaded onto a HiTrap 16/ 10 QFF column (Pharmacia) and washed with the buffer $(20 \mathrm{mM}$
Tris- $\mathrm{HCl}$ at $\mathrm{pH}$ 8.0, $1 \mathrm{mM}$ EDTA, and $1 \mathrm{M} \mathrm{NaCl})$. The flow-through fractions containing $3 \mathrm{CL}^{\text {pro }}$ were pooled and concentrated for growing crystals.

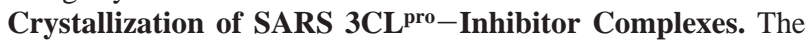
$3 \mathrm{CL}^{\text {pro }}$ protein was stored in a buffer containing $10 \mathrm{mM}$ Tris- $\mathrm{HCl}$ (pH 7.5), $1 \mathrm{mM}$ dithiothreitol (DTT), and $1 \mathrm{mM}$ EDTA and concentrated to $10 \mathrm{mg} / \mathrm{mL}$. The protein was mixed with the inhibitor TG-0205221 (15) dissolved in dimethyl sulfoxide (DMSO) in a 1:10 molar ratio and preincubated for at least $15 \mathrm{~min}$ prior to crystallization. The complex was cocrystallized by the sitting drop diffusion method at $18{ }^{\circ} \mathrm{C}$ for 4 days. The best crystals were obtained by mixing $2 \mu \mathrm{L}$ of $3 \mathrm{CL}^{\text {pro }}$ protein-inhibitor solution with $2 \mu \mathrm{L}$ of the reservoir solution (0.1 M MES at pH 6.5 and $4 \sim 8 \%$ (v/v) DMSO or MPD, $1 \mathrm{mM}$ DTT and 3 8\% (v/v) PEG6000) onto a sitting drop post, equilibrated with $1 \mathrm{~mL}$ of the reservoir solution.

X-ray Crystallography Data Collection and Processing. The crystals used for data collection were rinsed with the reservoir solution and cryo-cooled in liquid nitrogen. The X-ray data was collected by an RU300 X-ray generator with a Rigaku R-Axis IV ${ }^{++}$ image plate system. Data integration and scaling were performed by using the programs HKL2000. ${ }^{18}$ Data were reduced in the C2 space group. The unit cell dimensions are $a=109.0 \AA, b=81.2$ $\AA, c=53.3 \AA$, and $\beta=104.7^{\circ}$. There is one monomer in an asymmetric unit. The data collection statistics are summarized in Table S2.

Structure Solution and Refinement. The structures of the enzyme-inhibitor complex were determined by the molecular replacement method using the native structure taken from the Protein Data Bank (pdb code 1Z1I) as the starting model. Crossrotation function and translation function searches were performed with the program $\mathrm{CCP} 4 .{ }^{19}$ The geometric adjustments were made with XtalView ${ }^{20}$ under the guidance of $\left(2 F_{\mathrm{O}}-F \mathrm{c}\right)$ sum difference maps. The crystallography and NMR System (CNS) program ${ }^{21}$ was used for structure refinement, including simulated annealing procedure, positional, and B-factor refinements.

Graphics. The figures were prepared with PyMOL (DeLano Scientific; http://pymol. sourceforge.net/), ChemDraw, and LIGPLOT

Coordinates. Coordinates and structure factors for the structure of the SARS 3CL pro-TG-0205221 have been deposited in the Protein Data Bank under the pdb ID 2GX4.

3CL Protease Enzyme Assays. Fusion protein in which the SARS 3C-like protease or 229E 3C-like protease has been fused to the $E$. coli glutathione- $S$-transferase (GST) was expressed in $E$. coli BL21(DE3)pLysS cells (Novagen). The fusion protein GST$3 \mathrm{CL}^{\text {pro }}$ was purified by Glutathione Sepharose 4 Fast Flow (Pharmacia) affinity chromatography and cleaved with factor Xa to release $3 \mathrm{CL}^{\text {pro }}$. After removing the cleaved GST with glutathione sepharose, the recombinant protease was concentrated to $25 \mu \mathrm{M}$. The enzymatic activity of SARS $3 \mathrm{CL}^{\text {pro }}(75 \mathrm{nM})$ and $229 \mathrm{E} 3 \mathrm{CL}^{\text {pro }}$ (75 nM) was determined by incubation with $15 \mu \mathrm{M}$ substrate peptide (SITSAVLQSGFRKMA for SARS 3CL pro and VSYGSTLQAGLRKMA for $229 \mathrm{E} 3 \mathrm{CL}^{\text {pro }}$, respectively) at $25^{\circ} \mathrm{C}$ in $20 \mathrm{mM}$ Tris$\mathrm{HCl}$ (pH 7.5), $200 \mathrm{mM} \mathrm{NaCl}, 1 \mathrm{mM}$ EDTA, $1 \mathrm{mM}$ dithiothretol, and $1 \mathrm{mg} / \mathrm{mL}$ of bovine serum albumin for $30 \mathrm{~min}$. The reaction was terminated by adding equal volume of $0.2 \%$ trifluoroacetic acid, and the reaction mixture was analyzed with reverse-phase HPLC using a C18 column. Cleavage products were resolved using a $5-95 \%$ linear gradient of acetonitrile in $0.9 \%$ trifluoroacetic acid. Quantification of peak areas was used to determine the extent of substrate conversion. To determine the inhibitory effect of various compounds, the compound and the enzyme were preincubated at $25{ }^{\circ} \mathrm{C}$ for 20 min prior to the addition of the substrate. $K_{\mathrm{i}}$ was calculated using the equation of Cheng and Prusoff. ${ }^{22}$

Human Coronavirus HCoV 229E Viral Load Reduction Assay. Human coronavirus 229E was obtained from American Type Culture Collection (ATCC, VR-740) and cell-free viral stocks were prepared by infecting the human lung fibroblast cell line, MRC-5 (ATCC CCL-171), with HCoV 229E for 4 days. The aliquots of cell-free viral stock were stored at $-80^{\circ} \mathrm{C}$. For viral load reduction assay, the MRC-5 cells were preabsorbed with HCoV 229E (40 
pfu/well) for $1 \mathrm{~h}$. Serially diluted compounds were added to the culture following the removal of the unabsorbed virus. Cell culture supernatants were harvested after $96 \mathrm{~h}$, and TCID $_{50}$ for individual samples were determined using MRC-5 cells.

Human Coronavirus HCoV 229E Plaque Reduction Assay. MRC-5 cells were grown to $90 \%$ confluence in a 6-well plate and then incubated with serially diluted HCoV $229 \mathrm{E}$ for $1 \mathrm{~h}$. Cultures were overlayed with $0.3 \%$ agarose after the removal of the unabsorbed virus. Test compounds were added to the culture medium for 4 days. At the end of incubation, the cells were fixed with $10 \%$ formalin and stained with $0.5 \%$ crystal violet after the removal of agarose.

SARS Antiviral Activity Measurements. The initial screening for the compounds was carried out in 96-well microtiter plates. Two concentrations of individual compounds, for example, 20 and $10 \mathrm{mM}$, were tested in duplicated wells against SARS-CoV-induced CPE. We also included duplicate wells for treatment with compounds alone (w/o virus) to exclude any potential CPE of Vero E6 cells as a result of chemical toxicity. For each microtiter plate, uninfected and SARS-CoV-infected cells in quadruplicate were included as negative and positive controls, respectively. Thus, for a 96-well plate, we could test 11 different compounds. The maximum CPE (e.g., cellular round up and detachment of monolayers) and viral yields in the viral infected controls were consistently detected within 2 days post infection. Day 1: (a) Established permissive Vero E6 cells confluent monolayers with DMEM/10\% FCS medium (D-10) in 96-well flat-bottomed microtiter plates by seeding $2 \times 10^{4}$ cells per well in $100 \mathrm{~mL}$ of D-10 medium. It usually takes $16-18 \mathrm{~h}$ to reach greater than $90 \%$ confluence. (b) Made dilutions of compounds in D-10 medium. Two concentrations, 80 and $40 \mathrm{mM}$, were prepared for individual compounds. Day 2: (Most of the manipulation of the procedures were done in the BSL-3 laboratory.) (a) Added $50 \mathrm{~mL}$ of D-10 medium or diluted compounds into designated wells for individual compounds, cell alone and virus-infected controls. This was done in the BSL-2 laboratory. (b) Made infectious SARS-CoV stock at $2 \times 10^{3} \mathrm{TCID}_{50} / \mathrm{mL}$ in D-10 medium. The original stock is $1 \times$ $10^{7} \mathrm{TCID}_{50} / \mathrm{mL}$. (c) Added $50 \mathrm{~mL}$ of $\mathrm{D}-10$ medium (for negative or compound alone controls) or diluted viral stock (for positive controls and test wells; 100 TCID $_{50}$ particles/well or MOI is $0.001-$ 0.002). Incubated the sealed microtiter plates at $37^{\circ} \mathrm{C}$. The final concentrations of each compound will be 20 and $10 \mathrm{mM}$. (d) Observed and scored the CPE daily. According to our experience, SARS-CoV-induced CPE in Vero E6 cells usually appears within 2 days even at an extremely low MOI. Thus, we terminated the experiments between day 5 and 6 after infection.

Supporting Information Available: HPLC and ${ }^{1} \mathrm{H}$ NMR data of major compounds. This material is available free of charge via the Internet at http://pubs.acs.org.

Acknowledgment. This work was partially supported by grants SDRU01 and 93SDRU17 to TaiGen Biotechnology from the National Science Council, Taiwan and by grants to A.H.J.W. from Academia Sinica and the National Science Council (NSC-93-3112-B-001-011-Y).

\section{References}

(1) Lee, N.; Hui, D.; Wu, A.; Chan, P.; Cameron, P.; Joynt, G. M.; Ahuja A.; Yumg, M. Y.; Leung, C. B.; To, K. F.; Lui, M. D.; Szeto, C. C.; Chung, S.; Sung, J. J. Y. A major outbreak of severe acute respiratory syndrome in Hong Kong. N. Engl. J. Med. 2003, 348, 1986-1994.

(2) Drosten, C.; Günther, S.; Preiser, W.; ven der Werf, S.; Brodt, H.R.; Becker, S.; Rabenau, H.; Panning, M.; Kolesnikova, L.; Fouchier, R. A. M.; Berger, A.; Burguière, A.-M.; Cinatl, J.; Eickmann, M.; Escriou, N.; Grywna, K.; Kramme, S.; Manuguerra, J.; Müller, S.; Rickerts, V.; Stürmer, M.; Vieth, S.; Klenk, H.-D.; Osterhaus, A. D. M. E.; Schmitz, H.; Doerr, H. W. Identification of a novel coronavirus in patients with severe acute respiraory syndrome. N. Engl. J. Med. 2003, 348, 1967-1976.

(3) Ksiazek, T. G.; Erdman, D.; Goldsmith, C. S.; Zaki, S. R.; Peret, T.; Emery, S.; Tong, S.; Urbani, C.; Comer, J. A.; Lim, W.; Rollin, P. E.; Dowell, S. F.; Ling, A.-E.; Humphrey, C. D.; Shieh, W.-J.;
Guarner, J.; Paddock, C. D.; Rota, P.; Fields, B.; DeRisi, J.; Yang, J.-Y.; Cox, N.; Hughes, J. M.; LeDuc, J. W.; Bellini, W. J.; Anderson, L. J.; and the SARS Working Group. A novel coronavirus associated with severe acute respiratory syndrome. N. Engl. J. Med. 2003, 348, $1953-1966$

(4) Fouchier, R. A. M.; Kuiken, T.; Schutten, M.; van Amerongen, G.; van Doornum, G. J. J.; van der Hoogen, B. G.; Peiris, M.; Lim, W.; Stöhr, K.; Osterhaus, A. D. M. E. Aetiology: Koch's postulates fulfilled for SARS virus. Nature 2003, 423, 240.

(5) Peiris, J. S. M.; Lai, S. T.; Poon, L. L. M.; Guan, Y.; Yam, L. Y. C.; Lim, W.; Nicholls, J.; Yee, W. K. S.; Yan, W. W.; Cheung, M. T.; Cheng, V. C. C.; Chan, K. H.; Tssang, D. N. C.; Yung, R. W. H.; $\mathrm{Ng}$, T. K.; Yuen, K. Y. Coronavirus as a possible cause of severe acute respiratory syndrome. Lancet 2003, 361, 1319-1325.

(6) WHO press release, 5 July, 2003. http://www.who.int/mediacentre/ news/releases/2003/pr56/en/.

(7) Marra, M. A.; Jones, S. J. M.; Astell, C. R.; Holt, R. A.; BrooksWilson; A.; Butterfield, Y. S. N.; Khattra, J.; Asano, J. K.; Barber, S. A.; Chan, S. Y.; Cloutier, A.; Coughlin, S. M.; Freeman, G.; Girn, N.; Griffith, O. L.; Leach, S. R.; Mayo, M.; McDonald, H.; Montgomery, S. B.; Pandoh, P. K.; Petrescu, A. S.; Robertson, A. G.; Schein, J. E.; Siddiqui, A.; Smailus, D. E.; Stoot, J. M.; Yang, G. S.; Plummer, F.; Andonov, A.; Artsob, H.; Bastien, N.; Bernard, K.; Booth, T. F.; Bowness, D.; Czub, M.; Drebot, M.; Fernando, L.; Flick, R.; Garbutt, M.; Gray, M.; Grolla, A.; Jones, S.; Feldmann, H.; Meyers, A.; Kabain, A.; Li, Y.; Normand, S.; Stroher, U.; Tipples, G. A.; Tyler, S.; Vogrig, R.; Ward, D.; Watson, B.; Brunham, R. C.; Krajden, M.; Petric, M.; Skowronski, D. M.; Upton, C.; Roper, R. $\mathrm{L}$. The genome sequence of the SARS-associated coronavirus. Science 2003, 300, 1399-1404.

(8) Rota, P. A.; Oberste, M. S.; Monroe, S. S.; Nix, W. A.; Campagnoli, R.; Icenogle, J. P.; Peñaranda, S.; Bankamp, B.; Maher, K.; Chen, M.-H.; Tong, S.; Tamin, A.; Lowe, L.; France, M.; DeRisi, J. L.; Chen, Q.; Wang, D.; Erdman, D. D.; Peret, T. C. T.; Burns, C.; Ksiazek, T. G.; Rollin, P. E.; Sanchez, A.; Liffick, S.; Holloway, B.; Limor, J.; McCaustland, K.; Olsen-Rasmussen, M.; Fouchier, R.; Günther, S.; Osterhaus, A. D. M. E.; Drosten, C.; Pallansch, M. A.; Anderson, L. J.; Bellini, W. J. Characterization of a novel coronavirus associated with severe acute respiratory syndrome. Science $\mathbf{2 0 0 3}, 300$, $1394-1399$.

(9) Ruan, Y.; Wei, C. L.; Ling, A. E.; Vega, V. B.; Thoreau, H.; Se Thoe, S. Y.; Chia, J.-M.; Ng, P.; Chiu, K. P.; Lim, L.; Zhang, T.; Chan, K. P.; Lin, E. L. O.; Ng, M. L.; Leo, S. Y.; Ng, L. F. P.; Ren, E. C.; Stanton, L. W.; Long, P. M.; Liu, E. T. Comparative fulllength genome sequence analysis of 14 SARS coronavirus isolates and common mutations associated with putative origins of infection. Lancet 2003, 361, 1779-1785.

(10) Thiel, V.; Herold, J.; Schelle, B.; Siddell, S. G. Viral replicase gene products suffice for coronavirus discontinuous transcription. J. Virol. 2001, 75, 6676-6681

(11) Murphy, R. L. Reviving protease inhibitors: new data and more options. J. Acquired Immune Defic. Syndr. 2003, 33, S43-S52.

(12) Dragovich, P. S.; Prins, T. J.; Zhou, R.; Webber, S. E.; Marakovits, J. T.; Fuhrman, S. A.; Patick, A. K.; Matthews, D. A.; Lee, C. A.; Ford, C. E.; Burke, B. J.; Rejto, P. A.; Hendrickson, T. F.; Tuntland, T.; Brown, E. L.; Meador III, J. W.; Ferre, R. A.; Harr, J. E. V.; Kosa, M. B.; Worland, S. T. Structure-based design, synthesis, and biological evaluation of irreversible human rhinovirus $3 \mathrm{C}$ protease inhibitors. 4. Incorporation of P1 lactam moieties as L-glutamine replacements. J. Med. Chem. 1999, 42, 1213-1224. (b) Tian, Q.; Nayyar, N. K.; Babu, S.; Chen, L.; Tao, J.; Lee, S.; Tibbetts, A.; Moran, T.; Liou, J.; Guo, M.; Kennedy, T. P. An efficient synthesis of a key intermediate for the preparation of the rhinovirus protease inhibitor AG7088 via asymmetric dianionic cyanomethylation of N-Boc-L-(+)-glutamic acid dimethyl ester. Tetrahedron Lett. 2001, 42, 6807-6809. (c) Dragovich, P. S.; Webber, S. E.; Prins, T. J.; Zhou, R.; Marakovits, J. T.; Johnson Jr., T. O. (Agouron Pharmaceuticals, Inc.) Antipicornaviral compounds and compositions, their pharmaceutical uses, and materials for their synthesis. U.S. Patent 6531452 B1, 2003

(13) Anand, K.; Ziebuhr, J.; Wadhwani, P.; Mesters, J. R.; Hilgenfeld, R. Coronavirus main proteinase $\left(3 \mathrm{CL}^{\mathrm{prd}} \mathrm{X}\right)$ structure: Basis for design of anti-SARS drugs. Science 2003, 300, 1763-1767.

(14) Yang, H.; Yang, M.; Ding, Y.; Liu, Y.; Lou, Z.; Zhou, Z.; Sun, L.; Mo, L.; Ye, S.; Pang, H.; Gao, G. F.; Anand, H.; Bartlam, M.; Hilgenfeld, R.; Rao, Z. The crystal structures of severe acute respiratory syndrome virus main protease and its complex with an inhibitor. Proc. Natl. Acad. Sci. U.S.A. 2003, 100, 13190-13195.

(15) Hsu, M.-F.; Kuo, C.-J.; Chang, K.-T.; Chang, H.-C.; Chous, C.-C.; Ko, T.-P.; Shr, H.-L.; Chang, G.-G.; Wang, A. H.-J.; Liang, P.-H. Mechanism of the maturation process of SARS-CoV 3CL protease. J. Biol. Chem. 2005, 280, 31257-31266. 
(16) Hsyu, P.-H.; Pithavala, Y. K.; Gersten, M.; Penning, C. A.; Kerr, B. M. Pharmacokinetics and safety of an antirhinoviral agent, ruprintrivir, in healthy volunteers. Antimicrob. Agents. Chemother. 2002, 46, 392-397.

(17) Zhang, K. E.; Hee, B.; Lee, C. A.; Liang, B.; Potts, B. C. M. Liquid chromatography-Mass spectrometry and liquid chromatography-NMR characterization of in vitro metabolites of a potent and irreversible peptidomimetic inhibitor of rhinovirus 3C protease. Drug Metab. Dispos. 2001, 29, 729-734.

(18) Otwinowski, Z. and Minor, W. Processing of X-ray diffraction data collected in oscillation mode. Methods Enzymol. 1997, 276, 307326.

(19) Collaborative computational project, the CCP4 suite: programs for crystallography. Acta Crystallogr., Sect. D 1994, 50, 760-763.

(20) McRee, D. E. XtalView/Xfit-A versatile program for manipulating atomic coordinates and electron density. J. Struct. Biol. 1999, 125, $156-165$
(21) Brunger, A. T.; Adams, P. D.; Clore, G. M.; DeLano, W. L.; Gros P.; Grosse-Kunstleve, R. W.; Jiang, J. S.; Kuszewski, J.; Nilges, M.; Pannu, N. S.; Read, R. J.; Rice, L. M.; Simonson, T.; Warren, G. L. Crystallography \& NMR system: A new software suite for macromolecular structure determination. Acta Crystallogr., Sect. D $\mathbf{1 9 9 8 ,}$ 54, 905-921.

(22) Cheng, Y. and Prusoff, W. H. Relationship between the inhibition constant (K1) and the concentration of inhibitor which causes 50\% inhibition (I50) of an enzymatic reaction. Biochem. Pharmacol. 1973, 22, 3099-3108.

(23) Wallance, A. C.; Laskowski, R. A.; Thornton, J. M. Ligplot: a program to generate schematic diagrams of protein-ligand interactions. Protein Eng. 1995, 8, 127-134.

JM0603926 